Article

\title{
Pyrite Morphology as an Indicator of Paleoredox Conditions and Shale Gas Content of the Longmaxi and Wufeng Shales in the Middle Yangtze Area, South China
}

\author{
Ziyi Liu ${ }^{1,2} \mathbb{D}$, Dongxia Chen ${ }^{1,2, *}$, Jinchuan Zhang ${ }^{3}$, Xiuxiang L $\ddot{u ̈}^{1,2}$, Ziyi Wang ${ }^{1,2}$, \\ Wenhao Liao ${ }^{1,2}$, Xuebin Shi ${ }^{1,2}$, Jin Tang ${ }^{1,2}$ and Guangjie Xie ${ }^{1,2}$ \\ 1 State Key Laboratory of Petroleum Resources and Prospecting, China University of Petroleum, \\ Beijing 102200, China \\ 2 College of Geosciences, China University of Petroleum, Beijing 102200, China \\ 3 Key Laboratory of Shale Gas Exploration and Evaluation (Ministry of Land and Resources), China \\ University of Geosciences (Beijing), Beijing 100083, China \\ * Correspondence: lindachen@cup.edu.cn
}

Received: 26 April 2019; Accepted: 10 July 2019; Published: 12 July 2019

\begin{abstract}
Pyrite is the most common authigenic mineral preserved in many ancient sedimentary rocks. Pyrite also widely exists in the Longmaxi and Wufeng marine shales in the middle Yangtze area in South China. The Longmaxi and Wufeng shales were mainly discovered with 3 types of pyrites: pyrite framboids, euhedral pyrites and infilled framboids. Euhedral pyrites (Py4) and infilled framboids (Py5) belong to the diagenetic pyrites. Based on the formation mechanism of pyrites, the pyrites could be divided into syngenetic pyrites, early diagenetic pyrites, and late diagenetic pyrites. Under a scanning electron microscope (SEM), the syngenetic pyrites are mostly small framboids composed of small microcrystals, but the diagenetic pyrites are variable in shapes and the diagenetic framboids are variable in sizes with large microcrystals. Due to the deep burial stage, the pore space in the sediment was sharply reduced and the diameter of the late diagenetic framboids that formed in the pore space is similar to the diameter of the syngenetic framboids. However, the diameter of the syngenetic framboid microcrystals is suggested to range mainly from $0.3 \mu \mathrm{m}$ to $0.4 \mu \mathrm{m}$, and that of the diagenetic framboid microcrystals is larger than $0.4 \mu \mathrm{m}$ in the study area. According to the diameter of the pyrite framboids (D) and the diameter of the framboid microcrystals (d), the pyrite framboids could be divided into 3 sizes: syngenetic framboids (Py1, D $<5 \mu \mathrm{m}, \mathrm{d} \leq 0.4 \mu \mathrm{m}$ ), early diagenetic framboids (Py2, D $>5 \mu \mathrm{m}, \mathrm{d}>0.4 \mu \mathrm{m}$ ) and late diagenetic framboids (Py3, D $<5 \mu \mathrm{m}, \mathrm{d}>0.4 \mu \mathrm{m}$ ). Additionally, the mean size and standard deviation/skewness values of the populations of pyrite framboids were used to distinguish the paleoredox conditions during the sedimentary stage. In the study area, most of the pyrite framboids are smaller than $5 \mu \mathrm{m}$, indicating the sedimentary water body was a euxinic environment. However, pyrite framboids larger than $5 \mu \mathrm{m}$ in the shales indicated that the sedimentary water body transformed to an oxic-dysoxic environment with relatively low total organic carbon (TOC: $0.4-0.99 \%$ ). Furthermore, the size of the framboid microcrystals could be used to estimate the gas content due to thermochemical sulfate reduction (TSR). The process of TSR occurs with oxidation of organic matter $(\mathrm{OM})$ and depletes the $\mathrm{H}$ bond of the OM, which will influence the amount of alkane gas produced from the organic matter during the thermal evolution. Thus, syngenetic pyrites ( $\mathrm{d}$ ranges from $0.35 \mu \mathrm{m}$ to $0.37 \mu \mathrm{m}$ ) occupy the main proportion of pyrites in the Wufeng shales with high gas content $\left(1.30-2.30 \mathrm{~m}^{3} / \mathrm{t}\right.$ ), but the Longmaxi shales ( $\mathrm{d}$ ranges from 0.35 $\mu \mathrm{m}$ to $0.72 \mu \mathrm{m})$ with a relatively low gas content $\left(0.07-0.93 \mathrm{~m}^{3} / \mathrm{t}\right)$ contain diagenetic pyrites. Because of TSR, the increasing size of the microcrystals may result in an increase in the value of $\delta^{13} C_{1}$ and a decrease in the value of $\delta^{13} C_{1}-\delta^{13} C_{2}$. Consequently, the size of pyrite framboids and microcrystals could be widely used for rapid evaluation of the paleoredox conditions and the gas content in shales.
\end{abstract}


Keywords: syngenetic framboids; diagenetic framboids; paleoredox conditions; shale gas content; middle Yangtze area; South China

\section{Introduction}

Longmaxi and Wufeng shales were recognized as the most important hydrocarbon generating shales in the middle Yangtze area in China [1-4]. Many studies have been published on the sedimentology of the Longmaxi and Wufeng formation, as well as on reservoir structure, the characteristics of shale gas and the way of gaseous accumulation [5-9], but less attention has been paid to the discussion of authigenic minerals such as pyrites. The only research on the pyrites in the Longmaxi and Wufeng shales has been limited to the pore structure of the pyrite framboids [10-12]. However, the pyrite morphology could be used to indicate paleoredox conditions. More recently, the size distribution of pyrite framboids has been successfully applied as an indicator for an anoxic-euxinic environment in ancient marine sediments [13-17], and the formation of diagenetic pyrite is related to hydrocarbon activity which will influence the hydrocarbons generated from the organic matter [18,19]. Thus, pyrites could be used as indicators of the paleoredox conditions in the middle Yangtze area and as the impact on the hydrocarbon of the Longmaxi and Wufeng shales.

As a widely distributed mineral in marine shales [13,20], pyrite can be divided into syngenetic pyrite and diagenetic pyrite. Syngenetic pyrites are formed at the oxic-anoxic interface and then drop to the sediment surface when buoyancy cannot keep them suspended (Figure 1a) $[13,21,22]$. The framboid is generally considered to be the unique structural feature of syngenetic pyrite $[13,23,24]$. Generally, pyrite framboids are not precipitated as pyrite directly, but are transformed through intermediate phases of iron sulfides $[13,23,24]$. The growth of syngenetic pyrite is restricted after burial and the original framboids are preserved (the diameter of a syngenetic framboid is smaller than $5 \mu \mathrm{m}$ with small microcrystals). Therefore, syngenetic pyrite can be used to reflect the redox process of shale in a sedimentary water environment $[13,25,26]$. According to the different formation mechanisms of diagenetic pyrite, early diagenetic pyrites are formed in the sediments' porewater when the location of the oxic-anoxic interface falls down to the sediment (the diameter of an early diagenetic framboid is larger than $5 \mu \mathrm{m}$ with a broad size distribution) (Figure 1b) [13,22,25,26]. With the burial of sediment, the microcrystals of the early diagenetic pyrites will over grow by the reaction between Fe and $S$ from the porewater (Figure 1b). The formation of recrystallized pyrite (late diagenetic pyrite) and the overgrowth of early diagenetic pyrite are related to thermochemical sulfate reduction (TSR) [18,19]. The overall process of TSR can be summarized as the following simple reaction:

$$
\text { Hydrocarbons }+\mathrm{SO}_{4}^{2-} \rightarrow \text { alteredhydrocarbons }+ \text { solidbitumen }+\mathrm{H}_{2} \mathrm{~S}\left(\mathrm{HS}^{-}\right)+\mathrm{HCO}_{3}^{-}\left(\mathrm{CO}_{2}\right)+\mathrm{H}_{2} \mathrm{O}
$$

The process of TSR occurs with oxidation of organic matter (OM) and depletes the $\mathrm{H}$ bond of the organic matter, which will influence the amount of alkane gas produced from the organic matter [18,19]. Further, TSR can result in the destruction of hydrocarbons [27,28] and deplete the content of hydrocarbon [29]. In the process of TSR, the size of late diagenetic pyrite is influenced by the supply of reactants, pore space and growth time. Therefore, the late diagenetic framboids with large microcrystals are often small in size [30]. Additionally, the euhedral pyrites or the pyritic masses may be derived from the overgrowth of diagenetic framboids (Figure 1c) [30,31]. The euhedral pyrites, pyritic masses, infilled framboids, overgrown framboids, polyframboid aggregates and stratiform pyrites are formed during the diagenetic stage with more positive $\delta^{34} S$ values [32-34]. 

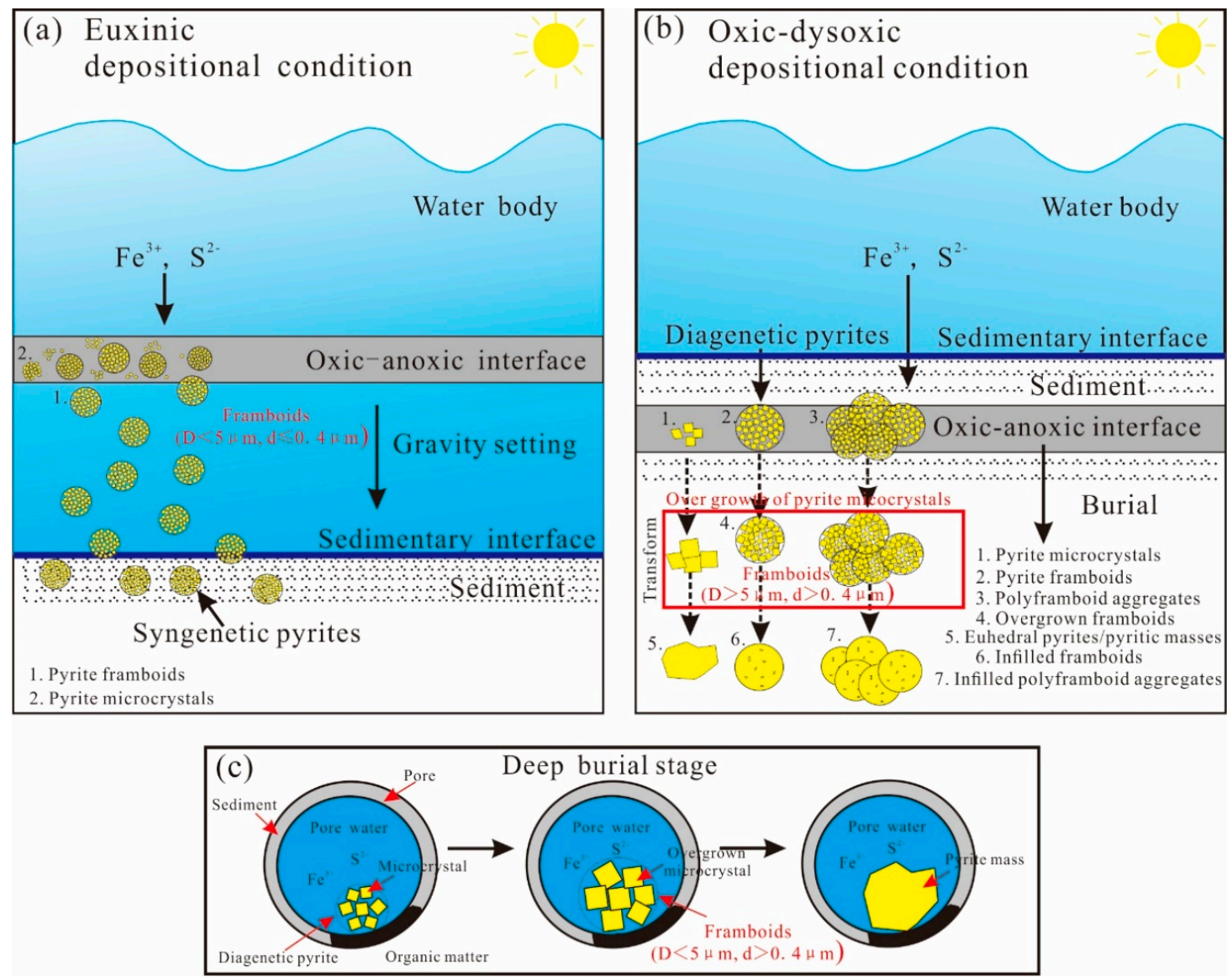

Figure 1. (a) Formation mechanism of syngenetic pyrites under the euxinic depositional conditions;

(b) formation mechanism of early diagenetic pyrites under the oxic-dysoxic depositional conditions [22];

(c) formation mechanism of late diagenetic pyrites in the deep burial stage.

In general, the sulfur isotopic composition of pyrite is used to distinguish the diagenetic and syngenetic pyrite populations. The value of $\delta^{34} S$ in syngenetic pyrite is generally negative, while the value of $\delta^{34} S$ in diagenetic pyrite is positive [32,35]. Additionally, the average value of $\delta^{34} S$ measured from the pyrite of the marine shales is $4.15 \%$, which is similar to the average value of $\delta^{34} \mathrm{~S}$ measured from sulfate $\left(2.19 \%\right.$ o) in the south of China [36]. However, the $\delta^{34} \mathrm{~S}$ in pyrites of bulk rock is often measured through a mass spectrometer coupled to an elemental analyzer, and the measured sulfur isotope is derived from the mixed values of sulfur isotopes from sedimentary pyrite and diagenetic pyrite. In addition to the above experimental method, the diagenetic and syngenetic pyrite populations are usually distinguished by the smaller mean size of the framboids and standard deviation/skewness values of the populations $[14,15,37,38]$. Because the diagenetic framboids vary in size, the standard deviation/skewness values of diagenetic framboids are larger than those of syngenetic framboids. This method could be used in an area with apparently variable framboid sizes. For example, the diameter of framboids varies broadly, ranging from $3 \mu \mathrm{m}$ to $25 \mu \mathrm{m}$ in the Late Cretaceous Qingshankou formation, Songliao Basin, Northeast China [22]. The size of the pyrite framboids is classified as presenting two populations, framboids $<15 \mu \mathrm{m}$ and framboids in the range $60-220 \mu \mathrm{m}$ in the Toarcian Oceanic Anoxic Event, South Iberian Paleomargin [17]. However, the method does not adapt to the pyrites in the Longmaxi and Wufeng shales in the middle Yangtze area, South China. Apart from most of the sizes of the diagenetic framboids are similar to the sizes of syngenetic framboids, the arithmetic mean and standard deviations to predict a subset of framboids is indeed not accurate [39]. The standard deviation/skewness values of diagenetic framboids are similar to those of syngenetic framboids. 
In this paper, the size of the framboid microcrystals has been used to distinguish diagenetic and syngenetic pyrite. Then, the size of the pyrite framboids could be used to analyze the paleoredox conditions of the water body in the study area. Furthermore, the relationship between pyrite morphology and shale gas content could be proposed by the size of the framboid microcrystals, which reflects the degree of pyrite recrystallization. The shale gas content could be influenced by the degree of pyrite recrystallization. Meanwhile, the carbon isotopes of alkanes will also be affected by the degree of pyrite recrystallization as a result of the TSR [40-45].

\section{Geological Setting}

The study area is mainly located in the Western Hunan and Hubei fold belt, which is a part of the middle Yangtze area in South China (Figure 2a) [46-49].
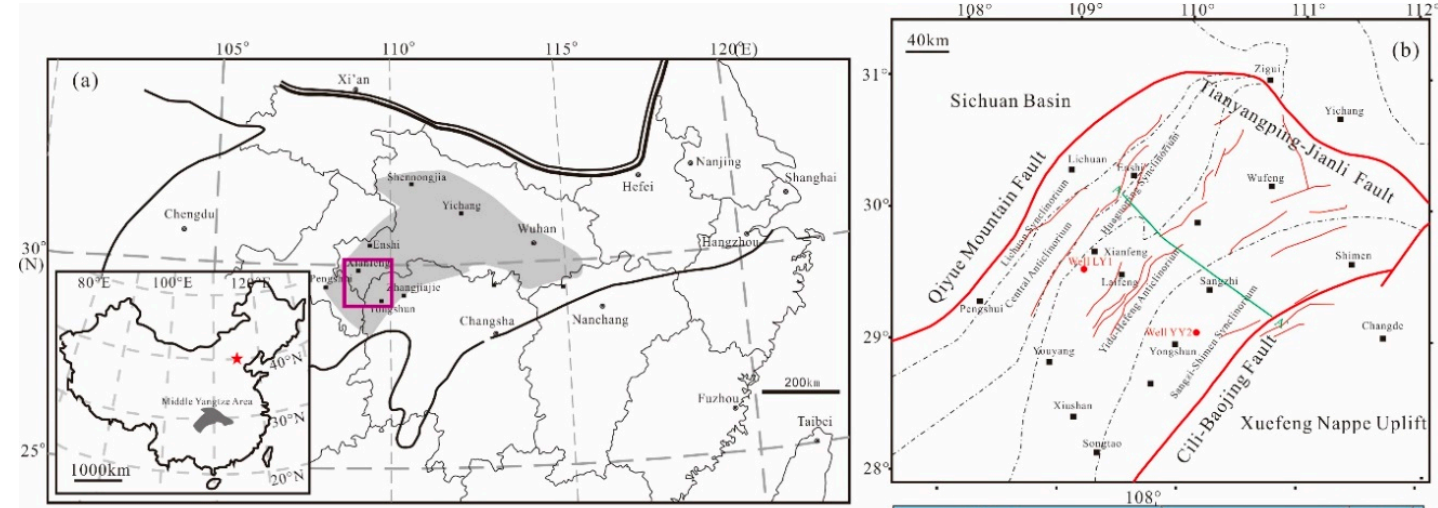

\begin{tabular}{|c|c|c|c|c|c|c|}
\hline (d) & \multicolumn{3}{|c|}{ Stratigraphy } & \multirow{2}{*}{$\begin{array}{l}\text { Thick- } \\
\text { ness(m) }\end{array}$} & \multirow{2}{*}{ Lithology } & \multirow{2}{*}{$\begin{array}{c}\text { Tectonic } \\
\text { Cycle }\end{array}$} \\
\hline System & Series & Formation & Sym. & & & \\
\hline \multirow{4}{*}{$\begin{array}{l}\text { Silurian } \\
\text { (S) }\end{array}$} & \multirow{4}{*}{ Lower } & Shamao & $\mathrm{S}_{1} \mathrm{~s}$ & $\sim 580$ & "."."."." & \multirow{8}{*}{ 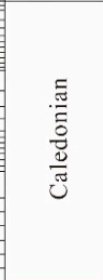 } \\
\hline & & Luoreping & $\mathrm{S}_{1} \mathrm{lr}$ & $\sim 890$ & & \\
\hline & & Xintang & $S_{1} x$ & & $\begin{array}{ll}-1-1-1- \\
=0\end{array}$ & \\
\hline & & Longmaxi & $\mathrm{S}_{1} 1$ & $\sim 830$ & & \\
\hline \multirow{4}{*}{$\begin{array}{l}\text { Ordovician } \\
\text { (O) }\end{array}$} & Upper- & Wufeng & $\mathrm{O}_{3} \mathrm{~W}$ & \multirow{2}{*}{$\sim 145$} & $\mathrm{Si}$ & \\
\hline & Middle & Miaopo & $\mathrm{O}_{2} \mathrm{~m}$ & & 1 & \\
\hline & \multirow{2}{*}{ Lower } & Guniutan & $\mathrm{O}_{1} \mathrm{~g}$ & \multirow{2}{*}{$\sim 600$} & \begin{tabular}{l|l} 
\\
1
\end{tabular} & \\
\hline & & Xilingxia & $\mathrm{O}_{1} \mathrm{x}$ & & $a_{1}$ & \\
\hline
\end{tabular}
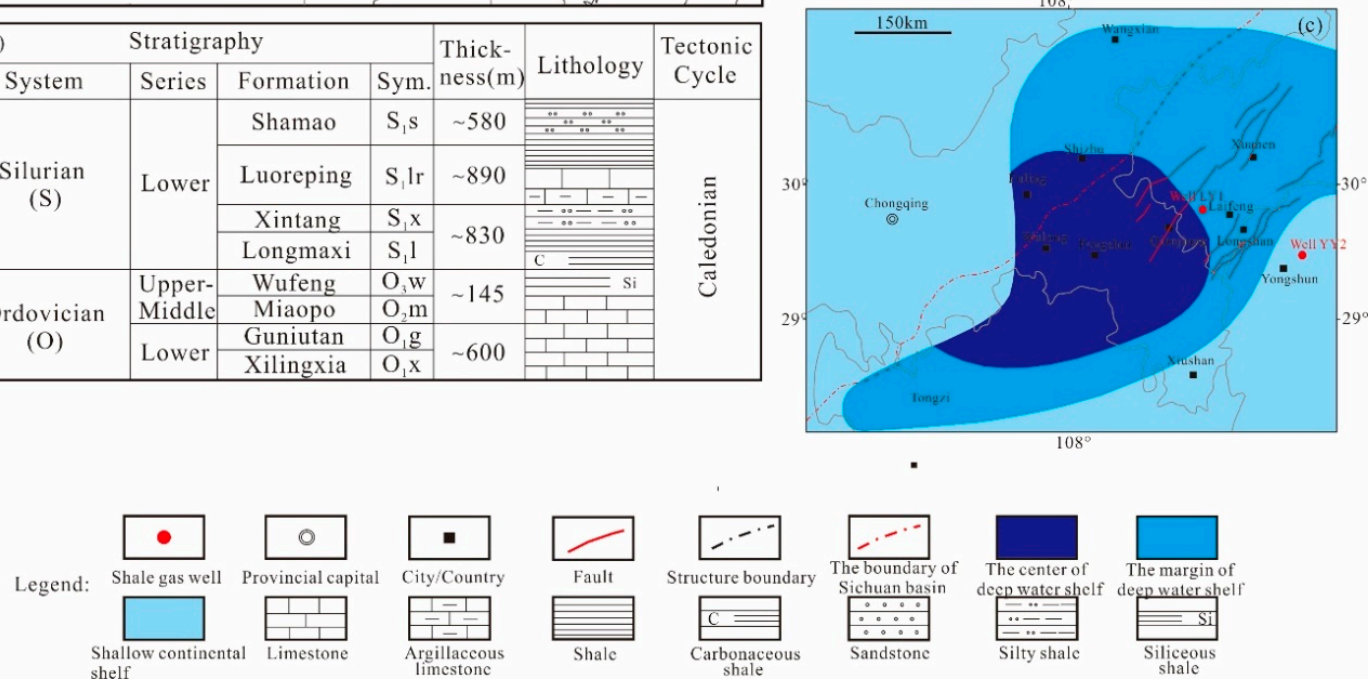

Figure 2. (a) The location of the study area in China; (b) the tectonic framework in the study area; (c) the sedimentary environment of the Longmaxi formation in the study area; (d) Simplified stratigraphic units in the middle Yangtze area and the Upper Ordovician Wufeng and the bottom of the lower Silurian Longmaxi formations. The wavy lines represent unconformities. Sym. = symbol.

For the tectonic setting, the study area is adjacent to the Sichuan basin in the west and the Jiangnan-Xuefeng nappe uplift in the east and consists of five tectonic units, namely, the Lichuan synclinorium, Yidu-Hefeng anticlinorium, Sangzhi-Shimen synclinorium, Huaguoping synclinorium and central anticlinorium (Figure 2b). Shale gas well LY1 was located at the syncline nucleus in the Yidu-Hefeng anticlinorium area, and shale gas well YY2 was located at the position of the syncline wing in the Sangzhi-Shimen synclinorium area. Both of the shale gas wells were located at positions far from faults (Figure 2b). 
The studied strata in the the middle Yangtze area involve the Lower Silurian Longmaxi formation and the Upper Ordovician Wufeng formation (Figure 2d). In the Late Ordovician period, the study area formed a subsiding basin with frequent alternations of carbonate and mudstone. Then, the depth of the water in the southeastern and northern areas gradually deepened in the early Silurian period. A large set of black shales was formed laterally in mainly the shallow continental shelf and deep shelf areas. From the center of deep water shelf to the shallow continental shelf, the thickness of black shales was reduced. Subsequently, the whole area was uplifted, and the strata were denuded extensively, which was influenced by Caledonian tectonic movement in the late Silurian $[50,51]$. The lower sections of the Longmaxi and Wufeng Formation approximately 50-60 m thick are widely distributed over the study area [52]. Of the two wells involved in this paper, one well is located in the margin of deep-water shelf area and the other in the shallow continental shelf area (Figure 2c). As the most important hydrocarbon generating formations, the Wufeng formation is composed of black siliceous shales and the lower section of the Longmaxi formation consists of black carbonaceous shales and silty shales (Figure 2d). Additionally, the middle and upper sections of the Longmaxi formation are composed of gray-green shales, yellow-green shales and siltstones. The colors change gradually upward, indicating that the sedimentary environment of the Longmaxi formation varied from the deep shelf to the shallow shelf [52]. The Upper Ordovician Wufeng formation was in the deep water shelf sedimentary setting. The thermal maturity of the organic matter is higher than that in the North American shale and has equivalent vitrinite reflectance values greater than $2 \%$ [53-56].

\section{Methods}

For analysis of the mineralogical composition, 11 core samples were collected from well LY1 and 8 core samples were collected from well YY2. All of samples were ground in an agate mortar with more than 800-mesh sieve. The mineralogical composition of 17 samples was characterized using the XRD patterns of randomly oriented powders by using a Bruker D8 Discover X-ray diffractometer (Table 1). The operation and calculation followed the relevant oil-industry standard of China (SY/T 5163-2010). The sample with a particle size smaller than $10 \mu \mathrm{m}$ was used to evaluate the total clay mineral content and the other nonclay mineral content [57].

Table 1. The mineralogical composition of 17 samples from well LY1 and well YY2 was derived based on the XRD analysis.

\begin{tabular}{|c|c|c|c|c|c|c|c|c|}
\hline \multirow{2}{*}{ Well } & \multirow{2}{*}{ Strata } & \multirow{2}{*}{ Depth (m) } & \multirow{2}{*}{ TOC (\%) } & \multicolumn{5}{|c|}{ Mineral Composition Content (\%) } \\
\hline & & & & Quartz & Felspar & Carbonate & Pyrite & Clay Mineral \\
\hline LY1 & $\mathrm{S}_{1} 1$ & 903 & 0.99 & 32.7 & 11.6 & 9.2 & 3.2 & 43.3 \\
\hline LY1 & $\mathrm{S}_{1} \mathrm{l}$ & 907 & 0.4 & 44.1 & 22.5 & 16.2 & 2.0 & 15.2 \\
\hline LY1 & $\mathrm{S}_{1} \mathrm{l}$ & 908 & 1.13 & 34.3 & 13.8 & 11.8 & 3.9 & 36.2 \\
\hline LY1 & $S_{1} 1$ & 917 & 0.43 & 42.3 & 25.1 & 15.8 & 2.2 & 14.6 \\
\hline LY1 & $S_{1} 1$ & 921 & 0.92 & 40.8 & 17.1 & 13.4 & 2.9 & 25.8 \\
\hline LY1 & $S_{1} 1$ & 925 & 1.13 & 39.9 & 17.0 & 13.4 & 2.1 & 27.6 \\
\hline LY1 & $S_{1} 1$ & 929 & 1.06 & 40.5 & 18.8 & 11.8 & 2.5 & 26.4 \\
\hline LY1 & $\mathrm{S}_{1} \mathrm{l}$ & 933 & 1.15 & 39.5 & 18.2 & 17.4 & 2.8 & 22.1 \\
\hline LY1 & $\mathrm{O}_{3} \mathrm{w}$ & 943 & 2.33 & 44.6 & 13.2 & 13 & 3.8 & 25.4 \\
\hline LY1 & $\mathrm{O}_{3} \mathrm{w}$ & 948 & 1.83 & 42.3 & 13.3 & 6.5 & 3.5 & 34.4 \\
\hline YY2 & $\mathrm{S}_{1} \mathrm{l}$ & 1503 & 0.28 & 38.7 & 15.4 & 8.6 & 0.2 & 37.1 \\
\hline YY2 & $S_{1} 1$ & 1510 & 0.99 & 42 & 25 & 6.0 & 2.0 & 25.0 \\
\hline YY2 & $S_{1} 1$ & 1511 & 1.12 & 40.4 & 15.8 & 7.5 & 4.5 & 31.6 \\
\hline YY2 & $S_{1} 1$ & 1512 & 1.05 & 35 & 28 & 3.0 & 3.0 & 31.0 \\
\hline YY2 & $S_{1} 1$ & 1515 & 1.10 & 46 & 21 & 2.0 & 4.0 & 27.0 \\
\hline YY2 & $\mathrm{S}_{1} \mathrm{l}$ & 1517 & 1.22 & 38.9 & 23 & 2.8 & 4.1 & 31.2 \\
\hline YY2 & $\mathrm{O}_{3} \mathrm{w}$ & 1520 & 5.39 & 41 & 20 & 2.0 & 5.0 & 32.0 \\
\hline
\end{tabular}

Notes: 1. $\mathrm{S}_{1} 1$ means Longmaxi formation. 2. $\mathrm{O}_{3} \mathrm{w}$ means Wufeng formation.

For pyrite morphological analyses, the chips of core samples were polished to $0.1 \mathrm{~mm}$ thickness using helium ion beams and cut into chips measuring $0.5 \mathrm{~cm} \times 1 \mathrm{~cm} \times 0.2 \mathrm{~mm}$ [58]. Then, the analyses 
were carried out under SU8010 cold field emission scanning electron microscope (SEM) equipped with low and high secondary-electron (SE) probes, black-scattered electrons (BSE) and an X-ray spectrometer (EDAX) at China University of Petroleum (Beijing). The pyrite morphological were obtained by SEM not optical methods. Then, the size of the pyrite framboids and the framboid microcrystals in the pictures were measured by the JMicroVision software (Version1.2.7, JMicroVision, Geneva, Switzerland), a software of image analysis similar to imageJ. Optical measurements underestimate the number of smaller framboids leading to larger arithmetic mean values. It is further interesting to note that the fit of the log-normal distribution is better for the SEM measurements than for the optical measurements [39].

The measured size of pyrite framboids are an approximation to within a $10 \%$ deviation because of the polished surface randomly intersecting the framboids [59].

The TOC data of 17 samples were measured by using a Leco CS-230 carbon analyzer in China University of Petroleum (Beijing, China). All samples were crushed and sieved with an 80-mesh sieve and then were blended with $10 \mathrm{vol} \% \mathrm{HCl}$ for one hour to eliminate the inorganic carbon. After that, all samples were washed with distilled water to remove all traces of HCl. Finally, the TOC analysis was performed using a Leco CS-230 carbon analyzer with $99.5 \%$ oxygen as carrier gas under the temperature of $24{ }^{\circ} \mathrm{C}$ and relative humidity of $48 \%$ [60].

The gas content data of 17 samples were collected from desorption of the core samples from well LY1 and well YY2. The gas content was quantified after the core sample was recovered at the drilling site. The sample was placed as quickly as possible inside a hermetically sealed canister saturated with salt water, and the volumes of gas released inside the canister were periodically measured using a graduated cylinder at atmospheric pressure $[61,62]$. The gas desorption instruments were provided by the China University of Geosciences (Beijing, China).

The analysis of stable carbon isotopes was carried out at the Nuclear Industry Beijing Geological Research Analysis and Test Research Centre. Stable carbon isotope values were determined on a Finnigan Mat Delta Plus mass spectrometer interfaced with an HP 5890II chromato-graph. Individual hydrocarbon gas components $\left(C_{1}-C_{4}\right)$ were separated on a gas chromatograph using a fused silica capillary column (PLOT Q $30 \mathrm{~m} \times 0.32 \mathrm{~mm}$ ). The GC oven was ramped from $35^{\circ} \mathrm{C}$ to $80{ }^{\circ} \mathrm{C}$ at $8{ }^{\circ} \mathrm{C} / \mathrm{min}$, then to $260^{\circ} \mathrm{C}$ at $5{ }^{\circ} \mathrm{C} / \mathrm{min}$, and maintained at the final temperature for $10 \mathrm{~min}$. Stable carbon isotopic values are reported in the $\delta$-notation in per mil (\%o) relative to the Vienna Pee Dee Belemnite (VPDB). The measurement precision was estimated to be $\pm 0.5 \%$ o for $\delta 13 C$ [63-65].

\section{Results}

\subsection{Pyrite Morphology in the Wufeng and Longmaxi Shales}

As a widely distributed mineral in marine shales $[13,20]$, pyrites appear with various shapes in Longmaxi and Wufeng shales in the middle Yangtze area, South China.

Core observation shows that the pyrites are not disorderly and irregularly distributed in the shales. Pyrites in the Longmaxi gray silty shales sometimes appear as stratiform pyrites, which can be seen as a layered distribution along the bedding surface of the shales (Figure 3a). Occasionally, the pyrites display a nodular form in the Longmaxi gray silty shales (Figure 3b). However, the pyrites in the Wufeng black shales are usually distributed in the form of thin strips along the bedding surface of shales (Figure 3c).

SEM analysis shows that the pyrites in the Wufeng and Longmaxi shales are mainly exhibits 3 types of pyrites: pyrite framboids, euhedral pyrites and infilled framboids. The pyrite framboids could be divided into 3 sizes: syngenetic framboids (Py1, D $<5 \mu \mathrm{m}, \mathrm{d} \leq 0.4 \mu \mathrm{m}$ ) distributed in the organic matter enrichment zone (Figure 4a,c,e,f), early diagenetic framboids (Py2, D $>5 \mu \mathrm{m}, \mathrm{d}>0.4 \mu \mathrm{m}$ ) (Figure 4c,e) and late diagenetic framboids (Py3, D $<5 \mu \mathrm{m}, \mathrm{d}>0.4 \mu \mathrm{m}$ ) (Figure 4b). Euhedral pyrites (Py4) occurring in the pores between clay minerals and organic matter (Figure 4a,c,d) and infilled framboids (Py5) keeping the shape of sphericity or sub-sphericity (Figure 4f) belong to the diagenetic 
pyrites. Further, the pyrites in the Wufeng and Longmaxi shales are enriched in syngenetic framboids (Py1, D $<5 \mu \mathrm{m}, \mathrm{d} \leq 0.4 \mu \mathrm{m}$ ) and diagenetic euhedral pyrites (Py4). However, the early diagenetic framboids (Py2, D $>5 \mu \mathrm{m}, \mathrm{d}>0.4 \mu \mathrm{m}$ ), late diagenetic framboids (Py3, D $<5 \mu \mathrm{m}, \mathrm{d}>0.4 \mu \mathrm{m}$ ) and diagenetic infilled framboids only exist in the Longmaxi shales.
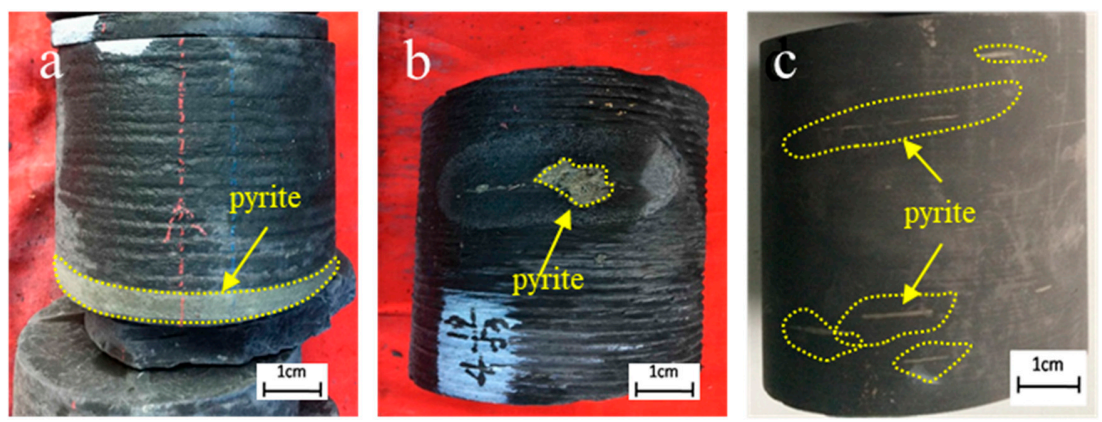

Figure 3. Core characteristics of the Longmaxi and Wufeng shales. (a) Stratiform pyrites in the gray silty shale of the Longmaxi formation, $921 \mathrm{~m}$, well LY1; (b) separate nodular pyrites in the gray silty shale of the Longmaxi formation, $917 \mathrm{~m}$, well LY1; (c) thin strips of pyrites in the Wufeng black shales, 1520 m, well YY2.
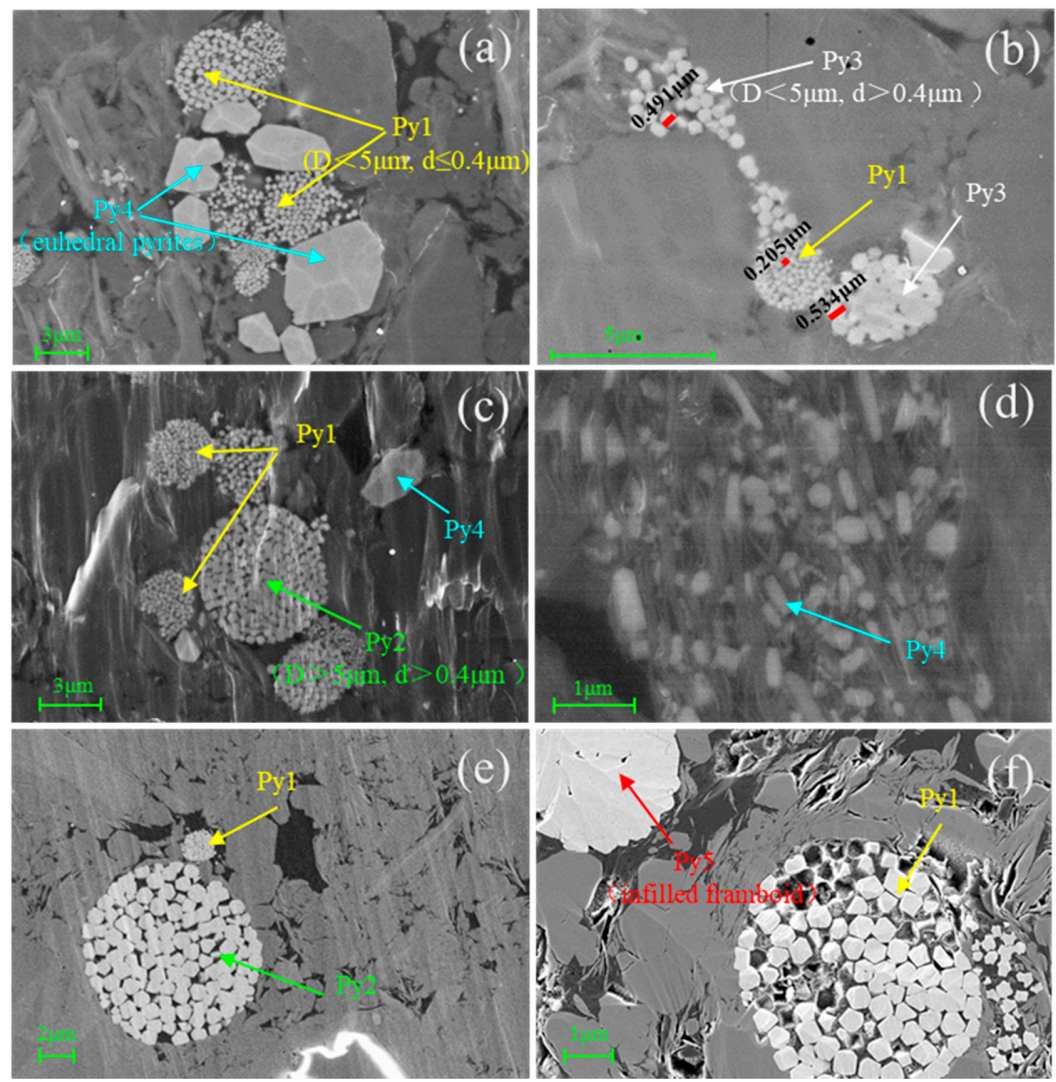

Figure 4. Pyrite micromorphology in the Longmaxi and Wufeng formations. (a) Syngenetic framboids (Py1) and small diagenetic euhedral pyrites (Py4) in the Wufeng black shale, $1520 \mathrm{~m}$, well YY2; (b) pyrite framboids of similar size with different sized microcrystals between the syngenetic framboids (Py1) and late diagenetic framboids (Py3) in the Longmaxi black shale, 1510 m, well YY2; (c) in addition to Py1 and Py4, the early diagenetic framboid pyrites (Py2) are observed in the Longmaxi black-gray shale, $903 \mathrm{~m}$, well LY1; (d) clay minerals and organic matter with euhedral pyrites in Lomgmaxi black shale, $925 \mathrm{~m}$, well LY1; (e) early diagenetic framboid pyrites (Py2) in the Lomgmaxi shale, $921 \mathrm{~m}$, well LY1; (f) infilled framboid (Py5) in the Longmaxi black shale, 1517 m, well YY2. 


\subsection{The size Distribution of Framboids and Microcrystals}

As shown in Figure 5, the main peak of the diameter of the microcrystals ranges from $0.3 \mu \mathrm{m}$ to $0.4 \mu \mathrm{m}$. Thus, the size of the syngenetic framboid microcrystals is suggested to range mainly from $0.3 \mu \mathrm{m}$ to $0.4 \mu \mathrm{m}$, and the diagenetic framboid microcrystals are larger than $0.4 \mu \mathrm{m}$. The interval from $0.4 \mu \mathrm{m}$ to $1.0 \mu \mathrm{m}$ includes the diagenetic framboid microcrystals.

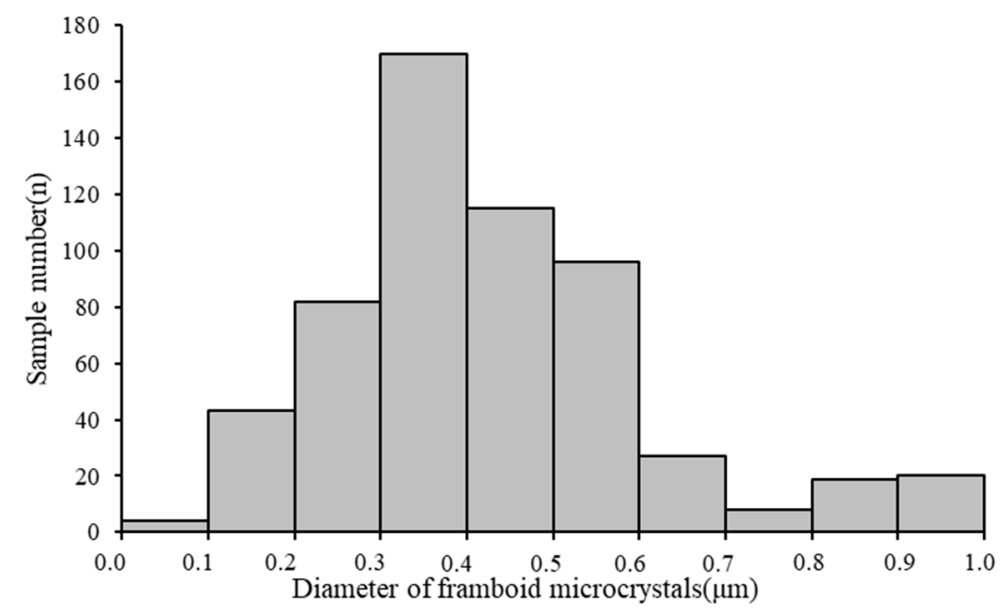

Figure 5. Distribution of the diameter of the framboid microcrystals in the Wufeng and Longmaxi formations.

According to the morphological characteristics of pyrite in the Wufeng and Longmaxi shales (Table 2), the statistics of the size distribution, such as standard deviation and skewness, have been calculated for 16 samples in the Wufeng and Longmaxi formations. The variation in standard deviation and skewness ranges from 0.62 to 2.94 and 0.03 to 3.86 , respectively, with an average of 1.71 and 1.19 , respectively. The average values of standard deviation and skewness of the Longmaxi framboids (1.73 and 1.35) are higher than those of the Wufeng framboids (1.62 and 0.51), which indicates that the pyrite framboids of the Longmaxi shales are more diverse and are larger than those of the Wufeng shales. Based on standard deviation and skewness, the pyrite framboids from euxinic and oxic-dysoxic environments have been plotted (Figure 6a,b). Most of the spots drop in the area of euxinic environments, except some spots from well LY1 that occur in oxic-dysoxic environments (Figure 6a,b). Meanwhile, the mean diameters of the framboids (Mean, D) range from $3.00 \mu \mathrm{m}$ to $5.59 \mu \mathrm{m}$, with an average of $4.23 \mu \mathrm{m}$, and more than $70 \%$ of the pyrite framboids in black shales or black siliceous shales are smaller than $5.0 \mu \mathrm{m}$ in mean size. Only a small number of the pyrite framboids have a mean size larger than $5.0 \mu \mathrm{m}$ in the Longmaxi black-gray shales, black-gray silty shales and gray silty shales (Figures 7 and 8). The mean diameters of the microcrystals of the framboids (Mean, $d$ ) range from $0.35 \mu \mathrm{m}$ to $0.72 \mu \mathrm{m}$, with an average of $0.45 \mu \mathrm{m}$, and the value of the Mean, $\mathrm{d}$ in the Wufeng black shales is lower than $0.4 \mu \mathrm{m}$. 
Table 2. Morphological characteristics of pyrite in the Wufeng and Longmaxi shales.

\begin{tabular}{|c|c|c|c|c|c|c|c|c|c|}
\hline Well & Strata & $\begin{array}{c}\text { Depth } \\
\text { (m) }\end{array}$ & $\begin{array}{c}\text { Mean, } \\
D(\mu \mathrm{m})\end{array}$ & $\begin{array}{c}\text { Mean, d } \\
(\mu \mathrm{m})\end{array}$ & $\begin{array}{l}\text { Standard } \\
\text { Deviation }\end{array}$ & Skewness & $\begin{array}{l}\text { Framboids } \\
\text { Measured }\end{array}$ & $\begin{array}{c}\text { TOC } \\
(\%)\end{array}$ & $\begin{array}{l}\text { Desorbed Gas } \\
\text { Content }\left(\mathrm{m}^{3} / \mathrm{t}\right)\end{array}$ \\
\hline YY2 & S11 & 1503 & 3.57 & 0.7 & - & - & 1 & 0.28 & 0.07 \\
\hline YY2 & S11 & 1510 & 4.33 & 0.42 & 2.05 & 1.17 & 57 & 0.99 & 0.55 \\
\hline YY2 & S11 & 1511 & 4.08 & 0.35 & 1.56 & 0.64 & 72 & 1.12 & 1.04 \\
\hline YY2 & S11 & 1512 & 3.36 & 0.37 & 1.01 & 0.03 & 56 & 1.05 & 0.69 \\
\hline YY2 & S11 & 1515 & 3.00 & 0.38 & 0.92 & 0.14 & 60 & 1.1 & 0.93 \\
\hline YY2 & S11 & 1517 & 4.00 & 0.4 & 1.35 & 0.95 & 70 & 1.22 & 0.44 \\
\hline YY2 & $\mathrm{O}_{3} \mathrm{~W}$ & 1520 & 4.46 & 0.35 & 1.47 & 0.72 & 90 & 5.39 & 2.30 \\
\hline LY1 & S11 & 903 & 5.12 & 0.48 & 2.69 & 3.86 & 79 & 0.99 & 0.46 \\
\hline LY1 & S11 & 907 & 5.32 & 0.72 & 2.94 & 2.71 & 64 & 0.4 & 0.15 \\
\hline LY1 & S11 & 908 & 3.82 & 0.38 & 1.3 & 0.2 & 69 & 1.13 & 0.57 \\
\hline LY1 & S11 & 917 & 5.45 & 0.43 & 2.53 & 2.51 & 69 & 0.43 & 0.42 \\
\hline LY1 & S11 & 921 & 5.59 & 0.68 & 2.18 & 2.09 & 55 & 0.92 & 0.34 \\
\hline LY1 & S11 & 925 & 3.34 & 0.49 & 1.43 & 1.34 & 43 & 1.13 & 0.45 \\
\hline LY1 & S11 & 929 & 4.11 & 0.39 & 1.97 & 1.78 & 60 & 1.06 & 0.64 \\
\hline LY1 & S11 & 933 & 3.65 & 0.41 & 0.62 & 0.13 & 56 & 1.15 & 0.61 \\
\hline LY1 & $\mathrm{O}_{3} \mathrm{w}$ & 943 & 4.61 & 0.37 & 1.84 & 0.28 & 92 & 2.33 & 1.30 \\
\hline LY1 & $\mathrm{O}_{3} \mathrm{~W}$ & 948 & 4.14 & 0.37 & 1.56 & 0.53 & 75 & 1.83 & 1.65 \\
\hline
\end{tabular}

Notes: 1. Mean, D means the mean diameter of framboids. 2. Mean, d means the mean diameter of microcrystals composing the framboids. 3 . The measurement precision was estimated to be $0.45 \%$ of measured value for TOC and $3 \%$ of measured value for gas content.
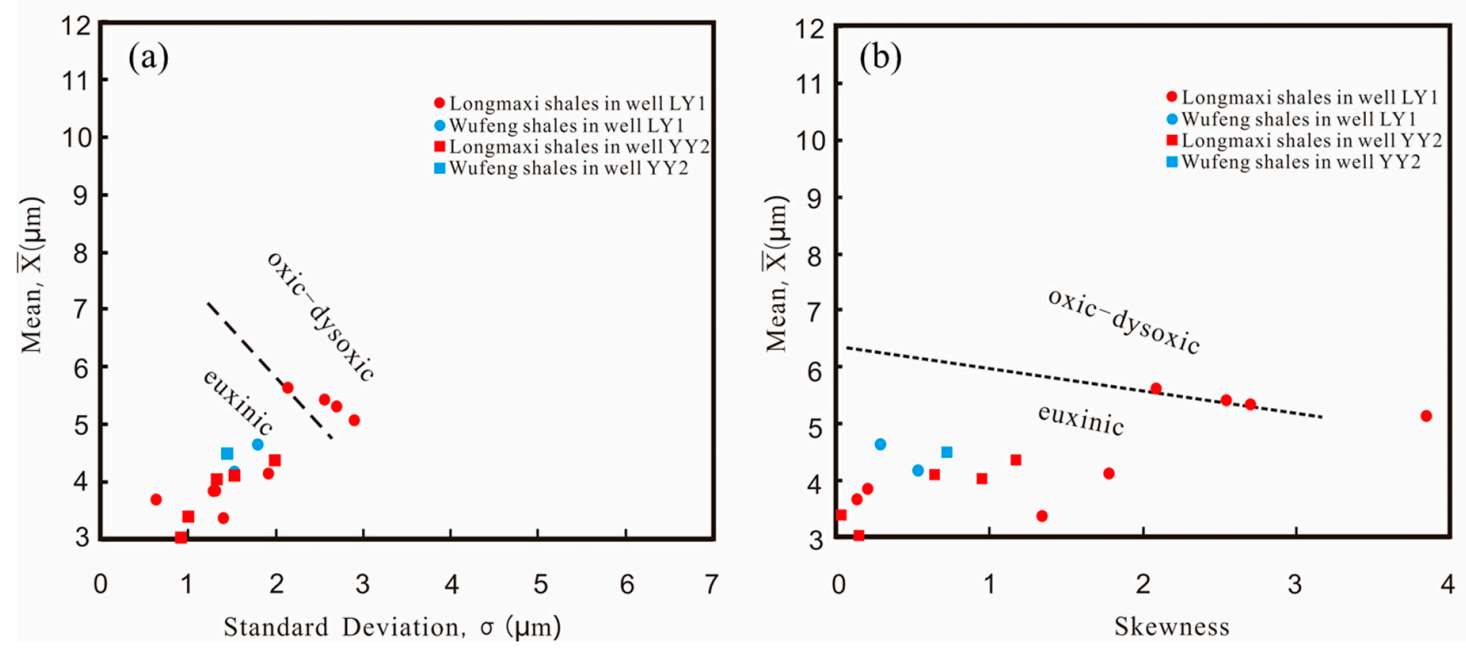

Figure 6. (a) Plot of the mean versus the standard deviation of the framboid size distribution of three wells. The dashed lines at the euxinic boundary and the oxic-dysoxic boundary are from Wei et al. (2016); (b) plot of the mean versus the skewness of the framboid size distribution of three wells. The dashed line is from Wei et al. (2016). 


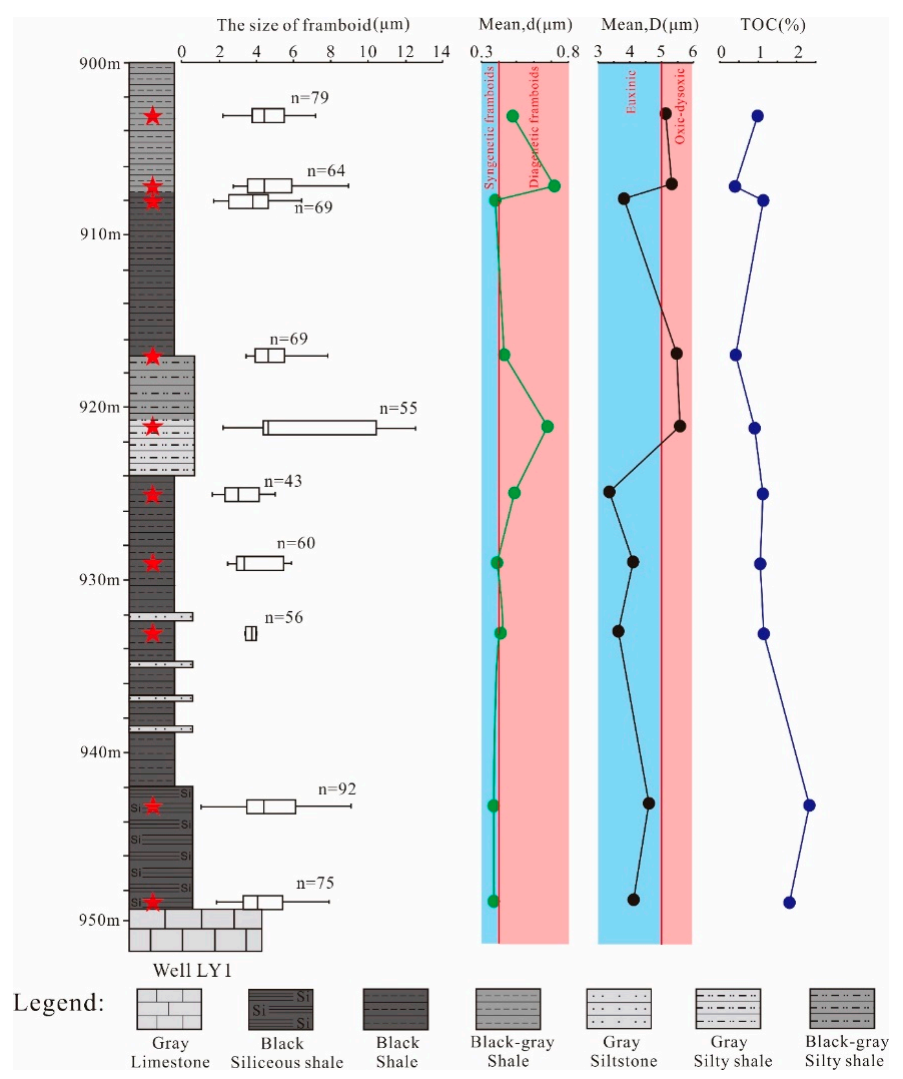

Figure 7. Size distribution of pyrite framboids, mean, D, mean, d, and TOC in the well LY1 shales.

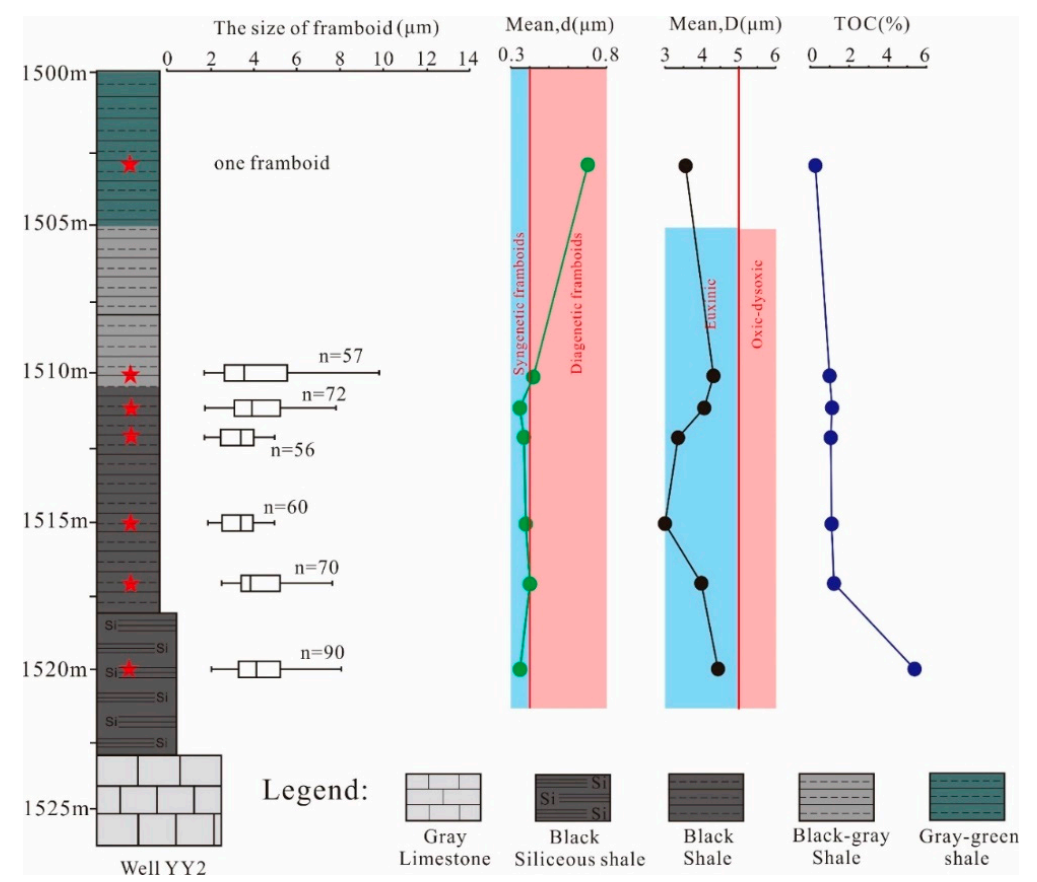

Figure 8. Size distribution of pyrite framboids, mean, D, mean, d, and TOC in the well YY2 shales.

Additionally, only one framboid could be observed in the Longmaxi gray-green shales at the depth of 1503 m with a low Mean, D and a relatively high Mean, d in well YY2 (Figure 7). 


\subsection{Characteristic of Shale Gas in the Wufeng and Longmaxi Shales}

As shown in Table 2, the gas content tends to increase with increasing depth. Compared to the gas content in the Longmaxi shales (the gas content ranges from $0.07-1.04 \mathrm{~m}^{3} / \mathrm{t}$ with an average of $0.53 \mathrm{~m}^{3} / \mathrm{t}$ ), relatively high gas content was discovered in the Wufeng shales (the gas content ranges from $1.30-2.30 \mathrm{~m}^{3} / \mathrm{t}$ with an average of $1.75 \mathrm{~m}^{3} / \mathrm{t}$ ) in the middle Yangtze area. Though the plot of TOC to gas content shows a relatively positive correlation (Figure 9a), the plot of pyrite content to gas content shows an unobvious correlation (Figure 9b). According to Table 2 and Figure 10, the gas content of the area with Mean, $\mathrm{d}>0.4 \mu \mathrm{m}$ is lower than that of the area with Mean, $\mathrm{d}<0.4 \mu \mathrm{m}$.
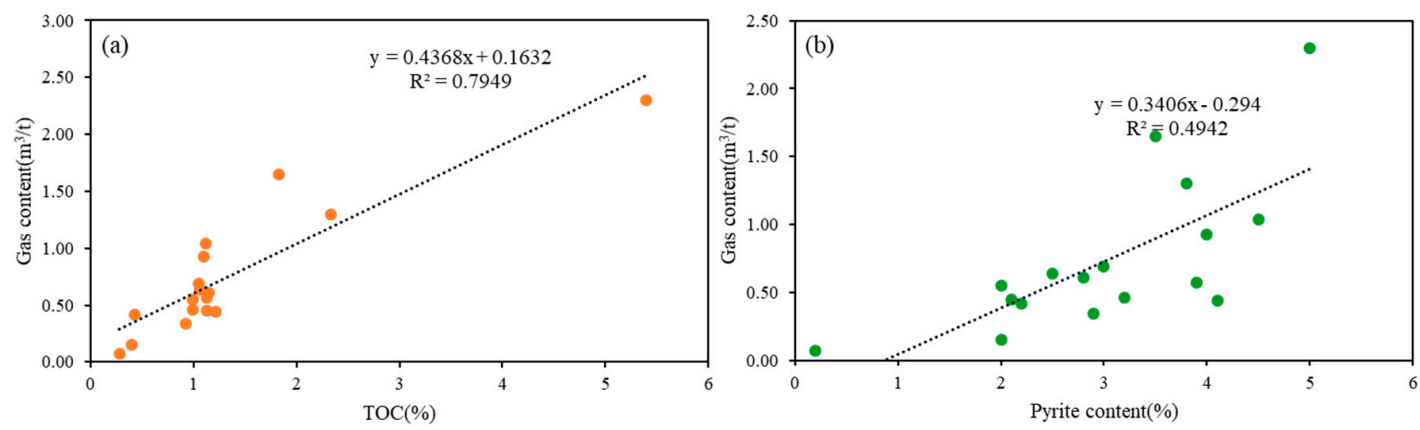

Figure 9. (a) Relationship between gas content and TOC values; (b) relationship between gas content and pyrite content for 17 shale samples from well YY2 and well LY1 in the middle Yangtze area, South China.

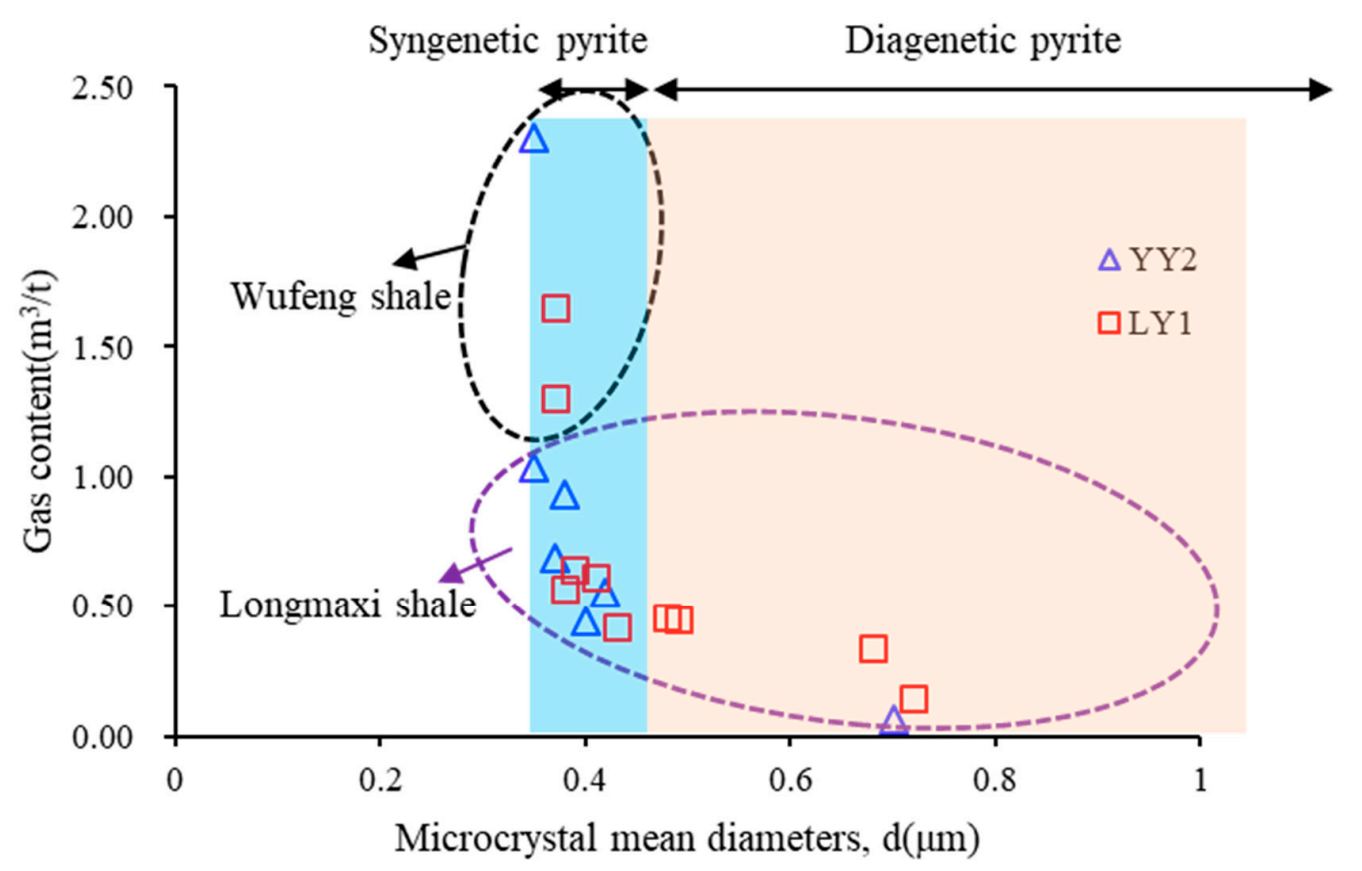

Figure 10. Different microcrystal diameters of pyrite framboids as indicators of the desorbed gas content.

For 10 gas samples from well YY2 and Well LY1, the $\delta^{13} C_{1}$ values range from $-38.4 \%$ o to $-30.2 \%$, while the $\delta^{13} C_{2}$ values range from $-41.5 \%$ o to $-35.5 \%$ o (Table 3). Additionally, the $\delta^{13} C_{1}\left(\%\right.$ o) $-\delta{ }^{13} C_{2}(\%$ o $)$ values range from $2.90 \%$ o to $5.50 \%$. As the microcrystals continue to grow larger than $0.4 \mu \mathrm{m}$, the value of $\delta^{13} C_{1}$ and $\delta^{13} C_{2}$ increases, while the value of $\delta^{13} C_{1}-\delta^{13} C_{2}$ decreases (Table 3, Figure 11). 
Table 3. Characteristics of microcrystalline mean diameters and the value of $\delta^{13} \mathrm{C}$.

\begin{tabular}{cccccc}
\hline Well & Depth & Mean,d & $\boldsymbol{\delta}^{\mathbf{1 3}} \mathbf{C}_{\mathbf{1}}(\mathbf{\% o})$ VPDB & $\boldsymbol{\delta}^{\mathbf{1 3}} \mathbf{C}_{\mathbf{2}}(\mathbf{\% o}) \mathbf{V P D B}$ & $\left.\boldsymbol{\delta}^{\mathbf{1 3}} \mathbf{C}_{\mathbf{1}}(\mathbf{\% o})-\boldsymbol{\delta}^{\mathbf{1 3}} \mathbf{C}_{\mathbf{2}} \mathbf{( \% o}\right)$ \\
\hline YY2 & 1511 & 0.35 & -38.0 & -41.0 & 3.00 \\
YY2 & 1512 & 0.37 & -38.2 & -41.1 & 2.90 \\
YY2 & 1515 & 0.38 & -38.3 & -41.2 & 2.90 \\
YY2 & 1520 & 0.35 & -38.4 & -41.3 & 2.90 \\
LY1 & 907 & 0.72 & -30.8 & -35.8 & 5.00 \\
LY1 & 917 & 0.43 & -32.9 & -38.4 & 5.50 \\
LY1 & 921 & 0.68 & -30.2 & -35.5 & 5.30 \\
LY1 & 925 & 0.49 & -32.4 & -37.7 & 5.40 \\
LY1 & 933 & 0.41 & -32.7 & -38.1 & 5.20 \\
LY1 & 943 & 0.37 & -36.3 & -41.5 & \\
\hline
\end{tabular}

Notes: 1. The measurement precision was estimated to be $\pm 0.5 \%$ of $\delta^{13} \mathrm{C}$.

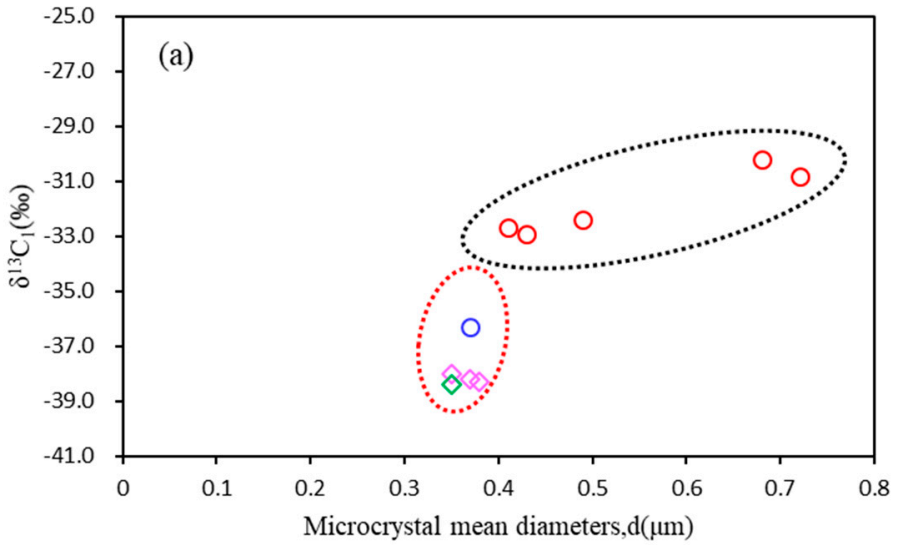

(a)

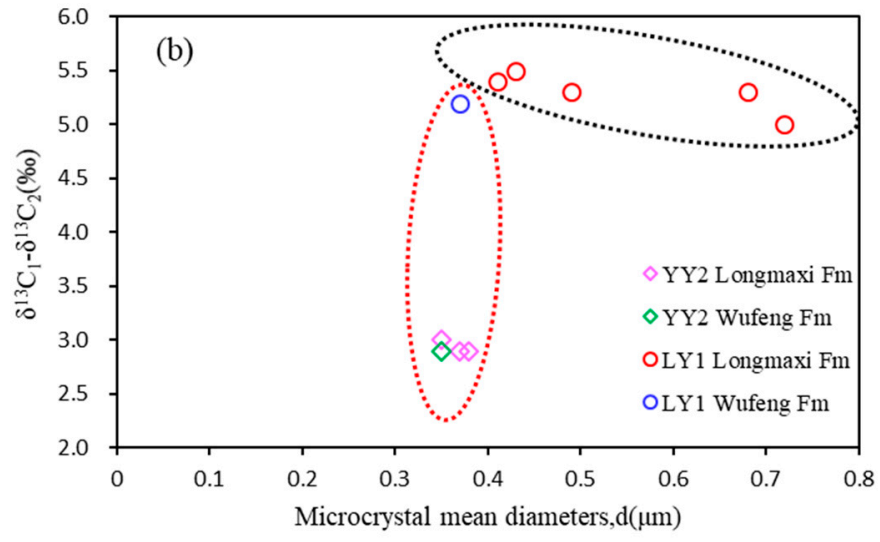

(b)

Figure 11. (a) Relationship between microcrystalline mean diameters and the value of the $\delta^{13} \mathrm{C}_{1}$; (b) relationship between microcrystalline mean diameters and the value of the $\delta^{13} C_{1}-\delta^{13} C_{2}$.

\section{Discussion}

\subsection{Pyrite Morphology as an Indicator of Paleoredox Conditions}

Based on the formation mechanism of pyrite framboids, the pyrite framboids can be used as an indicator of paleoredox conditions [13-17,38,60]. Syngenetic framboids will not grow after pyrites 
are precipitated from the water and deposited in the sediments $[13,66]$. Nevertheless, the early diagenetic framboids that form under oxic-dysoxic conditions [13,22] have a longer growth time than the syngenetic framboids. This process results in the size of the early diagenetic framboids being large and variable. Hence, the framboids' mean size and standard deviation/skewness values of the populations can be used to estimate the paleoredox conditions in the water body [13-15,37,38].

The framboids' mean size and standard deviation/skewness values of the populations from the well LY1 and well YY2 are given in Table 2. As shown in Figure 6a,b, most of the spots drop in the area of euxinic environments. In the area of euxinic environments, pyrites are mainly syngenetic framboids with a narrow size distribution. However, some spots from well LY1 occur in oxic-dysoxic environments due to the samples of the spots include the early diagenetic framboids with a variable size. Meanwhile, most of the Mean, D values of the pyrite framboids in the two wells are smaller than $5 \mu \mathrm{m}$ and reflect a euxinic environment with strongly reduction conditions in the study area (Figures 7 and 8$)[25,26,67]$. In addition, black-gray shales, black-gray silty shales and gray silty shales, all with relatively low TOC $(0.4 \%-0.99 \%)$, reflect relatively weak reduction conditions in the sedimentary water body in well LY1. The shales with a Mean, D larger than $5 \mu \mathrm{m}$ also indicate oxic-dysoxic conditions during the sedimentary process (Figure 7). In well YY2, the upper sections of the Longmaxi formation are composed of gray-green shales with low TOC $(0.28 \%)$, which may suggest a sedimentary environment with oxidation conditions (Figure 8). During oxidation, it is difficult to form pyrites in the sediments [25,67], and only one pyrite framboid had been found under the SEM.

Although the Longmaxi and Wufeng formations are located in the deep-water shelf area and shallow continental shelf area, the redox environment of the sedimentary water is still different. According to the pyrite morphology, the Longmaxi and Wufeng formations with black shales are suggested to have formed under a euxinic environment, but the Longmaxi formation with black-gray shales, black-gray silty shales and gray silty shales is suggested to have formed under an oxic-dysoxic environment. The gray-green shales of the Longmaxi formation with only one or no pyrite framboids reflect an oxidizing environment. When a euxinic environment is transformed into an oxic-dysoxic environment, the sediment pore water is probably provided with more materials (e.g., $\mathrm{Fe}^{3+}, \mathrm{SO}_{4}^{2-}$ and $\mathrm{O}_{2}$ ) which benefits the process of TSR in the Longmaxi shales. However, the Wufeng formation is suggested to have formed under a euxinic environment with insufficient material supply (e.g., $\mathrm{Fe}^{3+}$, $\mathrm{SO}_{4}^{2-}$ and $\mathrm{O}_{2}$ ). The pore waters are short of $\mathrm{Fe}^{3+}, \mathrm{SO}_{4}^{2-}$ and $\mathrm{O}_{2}$, result in the lack of late diagenetic framboids in the Wufeng shales. The process of TSR during the diagenesis period is not obvious in the Wufeng formation.

\subsection{Relationship between Pyrite Morphology and Gas Content}

According to the observation of core samples and the corresponding data of the gas content, we found that the shales with diverse gas contents are accompanied by different pyrite morphologies in the middle Yangtze area, South China. A large amount of syngenetic framboids indicates a strongly reduction environment in the water column $[15,22,25,68-72]$, which benefits the preservation of organic matter in the sediment. Thus, the shale that contains a number of syngenetic pyrites is usually the organic-rich shale. However, the relationship between TOC and pyrite content is not very good in the study area (Table 1) and the plot of pyrite content to gas content shows an unobvious correlation due to the existence of the late diagenetic pyrite (Figure $9 \mathrm{~b}$ ).

Redox reactions involving sulfate $\left(\mathrm{SO}_{4}^{2-}\right)$ and $\mathrm{OM}$ may occur during diagenetic processes $[18,73,74]$. In addition to sulfate reduction driven by bacterial sulfate reduction (BSR) at low temperatures during early diagenesis (i.e., $0<\mathrm{T}<60-80^{\circ} \mathrm{C}$ ), sulfate reduction can also occur chemically (thermochemical sulfate reduction: TSR) at higher temperatures $[18,73,74]$. Thermochemical sulfate reduction (TSR) accompanied with the formation of diagenetic pyrite results in the oxidation of organic matter (OM) and the loss of functional groups $[18,19]$, while $\mathrm{H}_{2} \mathrm{~S}$ produced from the TSR process in the source rock was depleted by iron in the shales $[18,65,75]$. Further, there is a significant negative correlation between the TOC content and $\delta^{34} S$ values of pyrite supporting the depletion of OM in the sections affected by 
TSR [19]. The process of TSR could lead to the destruction of hydrocarbons $[18,27,28]$ and the depletion of hydrocarbon content [29]. Meanwhile, TSR could give rise to highly aromatic, insoluble residues. These types of insoluble residues are usually pyrobitumens [18,27], and the pyrobitumens that are the final product of the organic thermal evolution cannot product alkanes again [76]. Additionally, the process of thermochemical sulfate reduction could result in depletion of the $\mathrm{H}$ bond of organic matter, which will influence the amount of alkane gas produced from the organic matter during the thermal evolution. Thus, with the increasing growth of late diagenetic pyrite and the overgrowth of the early diagenetic pyrites, the content of alkanes produced from OM became increasingly lower.

As shown in Figures 7 and 8, the sections of the Longmaxi formation with a Mean, d larger than $0.4 \mu \mathrm{m}$ is coupled with relatively low shale gas contents. The plot of microcrystalline mean diameters to gas content reflects the negative relationship between the formation of diagenetic pyrites and the shale gas content in the Wufeng and Longmaxi shales (Figure 10). In contrast to the shales with diagenetic pyrites $\left(\mathrm{d}>0.4 \mu \mathrm{m}\right.$ with a gas content range from $0.07 \mathrm{~m}^{3} / \mathrm{t}$ to $\left.0.61 \mathrm{~m}^{3} / \mathrm{t}\right)$, shales with syngenetic framboids $(\mathrm{d} \leq 0.4 \mu \mathrm{m})$ feature relatively high gas content $\left(0.44-2.30 \mathrm{~m}^{3} / \mathrm{t}\right)$ (Figure 10$)$. Thus, syngenetic framboids ( $\mathrm{d}$ ranges from $0.35 \mu \mathrm{m}$ to $0.37 \mu \mathrm{m}$ ) occupy the main proportion of pyrites in the Wufeng shales with high gas content $\left(1.30-2.30 \mathrm{~m}^{3} / \mathrm{t}\right.$ ). However, the Longmaxi shales ( $\mathrm{d}$ ranges from $0.35 \mu \mathrm{m}$ to $0.72 \mu \mathrm{m})$ contain some diagenetic pyrites that occur with relatively low gas content $\left(0.07-0.93 \mathrm{~m}^{3} / \mathrm{t}\right)$ (Table 2, Figure 10). Consequently, the more diagenetic pyrite that develops as overgrowths of the framboid microcrystals, the lower the shale gas content is in the Longmaxi and Wufeng shales.

The process of thermochemical sulfate reduction companied with the formation of diagenetic pyrite could also influence the carbon isotope of alkanes [40-45]. As shown in Figure 11a, as the microcrystals continue to grow greater than $0.4 \mu \mathrm{m}$, the value of $\delta^{13} \mathrm{C}_{1}$ increases. The thermochemical sulfate reduction (TSR) between sulfate and methane may result in the heavier carbon isotope of methane $[40,41,44,45]$. Furthermore, TSR could occur between sulfate and heavy hydrocarbon, which would result in the carbon isotope value of heavy hydrocarbon gas becoming heavier during the process $[18,42,43] . \delta^{13} C_{2}$ is more susceptible to TSR than $\delta^{13} C_{1}$, which leads to an increase in size of the microcrystals with a decreasing value of $\delta^{13} \mathrm{C} 1-\delta^{13} C_{2}$ (Table 3, Figure 11b).

\section{Conclusions}

(1) In the middle Yangtze area, the size of the pyrite framboid microcrystals is used to distinguish syngenetic pyrite and diagenetic pyrite due to their different formation mechanisms. The size of the syngenetic framboid microcrystals is suggested to range mainly from $0.3 \mu \mathrm{m}$ to $0.4 \mu \mathrm{m}$, and that of the diagenetic framboid microcrystals is larger than $0.4 \mu \mathrm{m}$. Pyrite framboids in the study area are divided into syngenetic framboids (Py1, D $<5 \mu \mathrm{m}, \mathrm{d} \leq 0.4 \mu \mathrm{m}$ ), early diagenetic framboids (Py2, D $>5 \mu \mathrm{m}$, $\mathrm{d}>0.4 \mu \mathrm{m}$ ) and late diagenetic framboids (Py3, D $<5 \mu \mathrm{m}, \mathrm{d}>0.4 \mu \mathrm{m}$ ).

(2) The sedimentary environment of the Longmaxi and Wufeng shales is mainly a euxinic environment with good reduction conditions. However, some part of the Longmaxi formation reflects an oxic-dysoxic environment with a lithology of black-gray shales, black-gray silty shales and gray silty shales. The gray-green shales of the Longmaxi formation with only one or no pyrite framboids reflect an oxidizing environment.

(3) The process of TSR accompanied with the formation of diagenetic pyrite results in oxidation of organic matter $(\mathrm{OM})$ and depletion of the $\mathrm{H}$ bond of $\mathrm{OM}$, which will influence the amount of alkane gas produced from the organic matter during the thermal evolution. The size of the framboid microcrystals could be used to estimate the shale gas content. Syngenetic pyrites (d ranges from $0.35 \mu \mathrm{m}$ to $0.37 \mu \mathrm{m}$ ) occupy the main proportion of pyrites in the Wufeng shales with high gas content $\left(1.30-2.30 \mathrm{~m}^{3} / \mathrm{t}\right)$, but the Longmaxi shales ( $\mathrm{d}$ ranges from $0.35 \mu \mathrm{m}$ to $0.72 \mu \mathrm{m}$ ) with relatively low gas content $\left(0.07-0.93 \mathrm{~m}^{3} / \mathrm{t}\right.$ ) contain diagenetic pyrites in the middle Yangtze area, South China. Due to thermochemical sulfate reduction (TSR), the increasing size of the microcrystals may result in an increase in the value of $\delta^{13} \mathrm{C}_{1}$ and a decrease in the value of $\delta^{13} C_{1}-\delta^{13} C_{2}$. 
Author Contributions: Conceptualization, Z.L. and D.C.; Methodology, Z.L.; Software, J.T.; Validation, J.Z., X.L. and X.S.; Formal Analysis, G.X.; Investigation, Z.L.; Resources, J.Z.; D.C., Z.W.; Writing-Original Draft Preparation, Z.L.; Writing-Review \& Editing, Z.L.; Visualization, Z.L.; Supervision, W.L.; Project Administration, D.C.; Funding Acquisition, D.C.

Funding: This work was supported by the Key Program of National Natural Science Foundation of China (41472110), The National Science and Technology Major Projects of China (2016ZX05034-001-05) and China Geological Survey (12120115007201).

Conflicts of Interest: The authors declare no conflict of interest.

\section{References}

1. Qiu, X.S.; Yang, B.; Hu, M.Y. Characteristics of shale reservoirs and gas content of Wufeng-Longmaxi Formation in middle Yangtze region. Nat. Gas Geosci. 2013, 24, 1274-1283. (In Chinese)

2. Nie, H.K.; Jin, Z.J.; Ma, X.; Liu, Z.B.; Lin, T.; Yang, Z.H. Graptolites zone and sedimentary characteristics of Upper Ordovician Wufeng Formation-Lower Silurian Longmaxi Formation in Sichuan Basin and its adjacent areas. Acta Pet. Sin. 2017, 38, 160-174. (In Chinese)

3. Zhao, Z.; Li, R.; Feng, W.; Yu, Q.; Yang, H.; Zhu, L.X. Enrichment conditions and favorable zone prediction of Wufeng-Longmaxi shale gas reservoirs in the northern Yunnan-Guizhou provinces, China. Nat. Gas Ind. 2017, 37, 26-34. (In Chinese)

4. Xiong, X.H.; Wang, J.; Xiong, G.Q.; Wang, Z.J.; Men, Y.P.; Zhou, X.L.; Zhou, Y.X.; Yang, X.; Deng, Q. Shale gas geological characteristics of Wufeng and Longmaxi formations in Northeast Chongqing and its exploration direction. Acta Geol. Sin. 2018, 92, 1948-1958. (In Chinese)

5. Curtis, J.B. Fractured shale-gas systems. AAPG Bull. 2002, 86, 1921-1938.

6. Chen, S.; Zhu, Y.; Wang, H.; Liu, H.; Wei, W.; Fang, J. Shale gas reservoir characterisation: A typical case in the southern Sichuan Basin of China. Energy 2011, 36, 6609-6616. [CrossRef]

7. Milliken, K.L.; Day-Stirrat, R.J.; Papazis, P.K.; Dohse, C. Carbonate lithologies of the mississippian Barnett shale, Fort Worth Basin, Texas. AAPG Mem. 2012, 97, 290-321.

8. Yang, C.; Zhang, J.C.; Tang, X.; Ding, J.H.; Zhao, Q.R.; Dang, W.; Chen, H.Y.; Su, Y.; Li, B.W.; Lu, D.F. Comparative study on micro-pore structure of marine, terrestrial, and transitional shales in key areas, China. Int. J. Coal Geol. 2017, 171, 76-92. [CrossRef]

9. Liu, Y.; Zhang, J.C.; Zhang, P.; Liu, Z.Y.; Zhao, P.W.; Huang, H.; Tang, X.; Mo, X.X. Origin and enrichment factors of natural gas from the lower Silurian Songkan Formation in northern Guizhou province, south China. Int. J. Coal Geol. 2018, 187, 20-29. [CrossRef]

10. Zhao, J.H.; Jin, Z.K.; Jin, Z.J.; Wen, X.; Geng, Y.K. Origin of authigenic quartz in organic-rich shales of the Wufeng and Longmaxi Formations in the Sichuan Basin, South China: Implications for pore evolution. J. Nat. Gas Sci. Eng. 2017, 38, 21-28. [CrossRef]

11. Xu, H.; Zhou, W.; Zhang, R.; Liu, S.M.; Zhou, Q.M. Characterizations of pore, mineral and petrographic properties of marine shale using multiple techniques and their implications on gas storage capability for Sichuan Longmaxi gas shale field in China. Fuel 2019, 241, 360-371. [CrossRef]

12. Nie, H.K.; Sun, C.X.; Liu, G.X.; Du, W.; He, Z.L. Dissolution pore types of the Wufeng Formation and the Longmaxi Formation in the Sichuan Basin, south China: Implications for shale gas enrichment. Mar. Pet. Geol. 2019, 101, 243-251. [CrossRef]

13. Wilkin, R.T.; Barnes, H.L.; Brantley, S.L. The size distribution of framboidal pyrite in modern sediments: An indicator of redox conditions. Geochim. Cosmochim. Acta 1996, 60, 3897-3912. [CrossRef]

14. Wilkin, R.T.; Barnes, H.L. Pyrite formation in an anoxic estuarine basin. Am. J. Sci. 1997, 297, 620-650. [CrossRef]

15. Wignall, P.B.; Newton, R.; Brookfield, M.E. Pyrite framboid evidence for oxygenpoor deposition during the Permian-Triassic crisis in Kashmir. Palaeogeogr. Palaeoclim. Palaeoecol. 2005, 216, 183-188. [CrossRef]

16. Pisarzowska, A.; Berner, Z.A.; Racki, G. Geochemistry of Early Frasnian (Late Devonian) pyrite-ammonoid level in the Kostomłoty Basin, Poland, and a new proxy parameter for assessing the relative amount of syngenetic and diagenetic pyrite. Sediment. Geol. 2014, 308, 18-31. [CrossRef]

17. Gallego-Torres, D.; Reolid, M.; Nieto-Moreno, V.; Martínez-Casado, F.J. Pyrite framboid size distribution as a record for relative variations in sedimentation rate: An example on the Toarcian Oceanic Anoxic Event in Southiberian Palaeomargin. Sediment. Geol. 2015, 330, 59-73. [CrossRef] 
18. Machel, H.G. Bacterial and thermochemical sulfate reduction in diagenetic settings-Old and new insights. Sediment. Geol. 2001, 140, 143-175. [CrossRef]

19. Ardakani, O.H.; Chappaz, A.; Sanei, H.; Mayer, B. Effect of thermal maturity on remobilization of molybdenum in black shales. Earth Planet. Sci. Lett. 2016, 449, 311-320. [CrossRef]

20. Wignall, P.B.; Newton, R. Pyrite framboid diameter as a measure of oxygen deficiency in ancient mudrocks. Am. J. Sci. 1998, 298, 537-552. [CrossRef]

21. Berner, R.A. Sedimentary pyrite formation. An update. Geochim. Cosmochim. Acta 1984, 48, 605-615. [CrossRef]

22. Wang, P.K.; Huang, Y.J.; Wang, C.S.; Feng, Z.H.; Huang, Q.H. Pyrite morphology in the first member of the Late Cretaceous Qingshankou Formation, Songliao Basin, Northeast China. Palaeogeogr. Palaeoclimatol. Palaeoecol. 2013, 385, 125-136. [CrossRef]

23. Love, L.G.; Amstutz, G.C. Review of microscopic pyrite from the Devonian Chattanooga Shale and Rammelsberg Banderz. Fortschr Miner. 1966, 43, 273-309.

24. Wang, X.J.; Zhang, S.Q.; Wei, M.J.; Mu, X.S.; Xu, T.W. Characteristics and formation mode of Es3 member pyrite in Wendong area of Dongpu depression. Fault Block Oil Gas Field 2015, 22, 178-183. (In Chinese)

25. Bond, D.P.G. Pyrite framboid study of marine Permian-Triassic boundary sections: A complex anoxic event and its relationship to contemporaneous mass extinction. Geol. Soc. Am. Bull. 2010, 122, 1265-1279. [CrossRef]

26. Wignall, P.B.; Bond, D.P.G.; Kuwahara, K.; Kakuwa, Y.; Newton, R.; Poulton, S.W. An 80 million year oceanic redox history from Permian to Jurassic pelagic sediments of the Mino-Tamba terrane, SW Japan, and the origin of four mass extinctions. Glob. Planet. Chang. 2010, 71, 109-123. [CrossRef]

27. Kelemen, S.R.; Walters, C.C.; Kwiatek, P.J.; Freund, H.; Afeworki, M.; Sansone, M.; Lamberti, W.A.; Pottorf, R.J.; Machel, H.G.; Peters, K.E.; et al. Characterization of solid bitumens originating from thermal chemical alteration and thermochemical sulfate reduction. Geochim. Cosmochim. Acta 2010, 74, 5305-5332. [CrossRef]

28. Hubert, E.K.; Walters, C.C.; Horn, W.C.; Zimmer, M.; Heines, M.M.; Lamberti, W.A.; Kliewer, C.; Pottorf, R.J.; Macleod, G. Sulfur isotopic analysis of bitumen and pyrite associated with thermal sulfate reduction in reservoir carbonates at the Big Piney-La Barge production complex. Geochim. Cosmochim. Acta 2014, 134, 210-220.

29. Ding, K.L.; Li, S.Y.; Yue, C.T.; Zhong, N.N. Review of thermochemical sulfate reduction. J. Univ. Pet. China 2005, 29, 150-155. (In Chinese)

30. Ye, Y.T.; Wu, C.D.; Zhai, L.N.; An, Z.Z. Pyrite morphology and episodic euxinia of the Ediacaran Doushantuo Formation in South China. Sci. China 2017, 60, 102-113. [CrossRef]

31. Lin, Z.Y.; Sun, X.M.; Peckmann, J.; Lu, Y.; Xu, L.; Strauss, H.; Zhou, H.Y.; Gong, J.L.; Lu, H.F.; Teichert, B.M.A. How sulfate-driven anaerobic oxidation of methane affects the sulfur isotopic composition of pyrite: A SIMS study from the South China Sea. Chem. Geol. 2016, 440, 26-41. [CrossRef]

32. Magnall, J.M.; Gleeson, S.A.; Stern, R.A.; Newton, R.J.; Poulton, S.W.; Paradis, S. Open system sulphate reduction in a diagenetic environment- Isotopic analysis of barite $\left(\delta^{34} \mathrm{~S}\right.$ and $\left.\delta^{18} \mathrm{O}\right)$ and pyrite $\left(\delta^{34} \mathrm{~S}\right)$ from the Tom and Jason Late Devonian Zn-Pb-Ba deposits, Selwyn Basin, Canada. Geochim. Cosmochim. Acta 2016, 180, 146-163. [CrossRef]

33. Raiswell, R. Pyrite texture, isotopic composition and the availability of iron. Am. J. Sci. 1982, 82, 1244-1263. [CrossRef]

34. Sawlowicz, Z. Pyrite framboids and their development: A new conceptual mechanism. Geol. Rundsch. 1993, 82, 148-156. [CrossRef]

35. Canfield, D.E. The evolution of the earth surface sulfur reservoir. Am. J. Sci. 2004, 304, 839-861. [CrossRef]

36. Fu, X.D.; Qiu, N.S.; Qin, J.Z.; Ten, G.E.; Liu, W.H.; Wang, X.F. Content distribution and isotopic composition characteristics of sulfur in matrine source rocks in Middle-Upper Yangtze region. Pet. Geol. Exp. 2013, 35, 545-551. (In Chinese)

37. Wilkin, R.T.; Barnes, H.L. Formation processes of framboidal pyrite. Geochim. Cosmochim. Acta 1997, 61, 323-339. [CrossRef]

38. Wei, H.Y.; Wei, X.M.; Qiu, Z.; Song, H.Y.; Shi, G. Redox conditions across the G-L boundary in South China: Evidence from pyrite morphology and sulfur isotopic compositions. Chem. Geol. 2016, 440, 1-14. [CrossRef]

39. Rickard, D. Sedimentary pyrite framboid size-frequency distributions: A meta-analysis. Palaeogeogr. Palaeoclimatol. Palaeoecol. 2019, 522, 62-75. [CrossRef] 
40. Cai, C.F.; Xie, Z.Y.; Worden, R.H.; Hu, G.Y.; Wang, L.S.; He, H. Methane-dominated thermochemical sulphate reduction in the Triassic Feixianguan Formation in East Sichuan Basin, China: Towards prediction of fatal $\mathrm{H}_{2} \mathrm{~S}$ concentrations. Mar. Pet. Geol. 2004, 21, 1265-1279. [CrossRef]

41. Cai, C.F.; Zhang, C.M.; He, H.; Tang, Y.J. Carbon isotope fractionation during methane-dominated TSR in East Sichuan Basin gasfields, China: A review. Mar. Pet. Geol. 2013, 48, 100-110. [CrossRef]

42. Hao, F.; Guo, T.; Zhu, Y.; Cai, X.; Zou, H.; Li, P. Evidence for multiple stages of oil cracking and thermochemical sulfate reduction in the Puguang gas field, Sichuan Basin, China. AAPG Bull. 2008, 92, 611-637. [CrossRef]

43. Xia, X.Y.; Ellis, G.S.; Ma, Q.S.; Tang, Y.C. Compositional and stable carbon isotopic fractionation during non-autocatalytic thermochemical sulfate reduction by gaseous hydrocarbons. Geochim. Cosmochim. Acta 2014, 139, 472-486. [CrossRef]

44. Jenden, P.D.; Titley, P.A.; Worden, R.H. Enrichment of nitrogen and ${ }^{13} \mathrm{C}$ of methane in natural gases from the Khuff Formation, Saudi Arabia, caused by the thermochemical sulfate reduction. Org. Geochem. 2015, 82, 54-68. [CrossRef]

45. Li, K.K.; George, S.C.; Cai, C.F.; Gong, S.; Sestak, S.; Armand, S.; Zhang, X.F. Fluid inclusion and stable isotopic studies of thermochemical sulfate reduction: Upper Permian and lower Triassic gasfields, northeast Sichuan Basin, China. Geochim. Cosmochim. Acta 2019, 246, 86-108. [CrossRef]

46. $\mathrm{Hu}, \mathrm{X}$. Oil and gas reservoir types in the western region of Hunan and Hubei and exploration orientation. Oil Gas Geol 2002, 23, 300-306. (In Chinese)

47. Long, Y. Lower Paleozoic shale gas exploration potential in the central Yangtze area, China. Geol. Bull. China 2011, 30, 344-348. (In Chinese)

48. Wang, J.; Li, X.; Huang, W. The shale gas exploration prospect assess of the Niutitang formation in western Hubei and Hunan-eastern Chongqing. Geol. Sci. Technol. Inf. 2014, 33, 98-103. (In Chinese)

49. Wang, Y.; Zhu, Y.; Chen, S.; Li, W. Characteristics of the nanoscale pore structure in Northwestern Hunan shale gas reservoirs using field emission scanning electron microscopy, high-pressure mercury intrusion, and gas adsorption. Energy Fuels 2014, 28, 945-955. [CrossRef]

50. Chen, K.; Zhang, J.C.; Tang, X.; Yu, J.D.; Liu, Y.; Yang, C. Lower Silurian Longmaxi formation shale adsorption capacity and main controlling factors analysis in western Hunan and Hubei areas. Oil Gas Geol. 2016, 37, 23-29. (In Chinese)

51. Yao, M.J.; Bao, H.Y.; Ding, Q.; Long, Y.K.; Liu, C.; Wang, Y.C. Stratigraphic and sedimentary characteristics of Wufeng-Longmaxi formation in the western Hunan-Hubei region. Geol. Miner. Resour. South China 2016, 32, 191-197. (In Chinese)

52. Hu, J.A.; Tang, S.H.; Zhang, S.H. Investigation of pore structure and fractal characteristics of the Lower Silurian Longmaxi shales in western Huan and Hubei Provinces in China. J. Nat. Gas Sci. Eng. 2016, 28, 522-535. [CrossRef]

53. Fan, E.; Tang, S.; Jiang, W.; Sun, C.; Zhang, C. Accumulation conditions and exploration potential of shale gas in Lower Silurian Longmaxi Formation. Northwestern Hunan. Xi'an Shiyou Univ. Nat. Sci. Ed. 2014, 29, 7-30.

54. Yang, F.; Ning, Z.; Liu, H. Fractal characteristics of shales from a shale gas reservoir in the Sichuan Basin, China. Fuel 2014, 115, 378-384. [CrossRef]

55. Yang, N.; Tang, S.; Zhang, S.; Jiang, W.; Zhu, W. Geological conditions and favorable exploration zones of shale gas in Longmaxi formation of North-western Hunan area. Coal Sci. Technol. 2014, 42, 104-108.

56. Wan, Y.; Pan, Z.J.; Tang, S.H.; Connell, L.D.; Down, D.D.; Camilleri, M. An experimental investigation of diffusivity and porosity anisotropy of a Chinese gas shale. Nat. Gas Sci. Eng. 2015, 23, 70-79. [CrossRef]

57. Chen, Q.; Zhang, J.; Tang, X.; Dang, W.; Li, Z.M.; Liu, C.; Zhang, X.Z. Pore Structure Characterization of the Lower Permian Marine Continental Transitional Black Shale in the Southern North China Basin, Central China. Energy Fuels 2016, 30, 10092-10105. [CrossRef]

58. Liu, Y.C.; Chen, D.X.; Qiu, N.S.; Wang, Y.; Fu, J.; Hu, Y.Y.; Jia, J.K.; Wu, H. Reservoir characteristics and methane adsorption capacity of the Upper Triassic continental shale in Western Sichuan Depression, China. Aust. J. Earth Sci. 2017, 64, 807-823. [CrossRef]

59. Cashman, K.V.; Marsh, B. Crystal size distribution (CSD) in rocks and the kinetics and dynamics of crystallization II: Makaopuhil lava lake. Contrib. Miner. Pet. 1988, 99, 292-305. [CrossRef] 
60. Chen, G.; Gang, W.Z.; Liu, Y.Z.; Wang, N.; Jiang, C.; Sun, J.B. Organic matter enrichment of the Late Triassic Yanchang Formation (Ordos Basin, China) under dysoxic to oxic conditions: Insights from pyrite framboid size distributions. J. Asian Earth Sci. 2019, 170, 106-117. [CrossRef]

61. Mavor, M.; Nelson, C. Coalbed Reservoir Gas-In-Place Analysis: GRI-97/0263; Gas Research Institute: Chicago, IL, USA, 1997.

62. Ma, Y.; Zhong, N.N.; Li, D.H.; Pan, Z.J.; Cheng, L.J.; Liu, K.Y. Organic matter/clay mineral intergranular pores in the lower Cambrian lujiaping shale in the north-eastern part of the upper Yangtze area, China: A possible microscopic mechanism for gas preservation. Int. J. Coal Geol. 2015, 137, 38-54. [CrossRef]

63. Ni, Y.Y.; Dai, J.X.; Zhu, G.Y.; Zhang, S.C.; Zhang, D.J.; Su, J.; Tao, X.W.; Liao, F.R.; Wu, W.; Gong, D.Y.; et al. Stable hydrogen and carbon isotopic ratios of coal-derived and oil-derived gases: A case study in the tarim basin, NW China. Int. J. Coal Geol. 2013, 116, 302-313. [CrossRef]

64. Dai, J.X.; Gong, D.Y.; Ni, Y.Y.; Huang, S.P.; Wu, W. Stable carbon isotopes of coal-derived gases sourced from the Mesozoic coal measures in China. Org. Geochem. 2014, 74, 123-142. [CrossRef]

65. Dai, J.X.; Zou, C.N.; Liao, S.M.; Dong, D.Z.; Ni, Y.Y.; Huang, J.L.; Wu, W.; Gong, D.Y.; Huang, S.P.; Hu, G.Y. Geochemistry of the extremely high thermal maturity Longmaxi shale gas, southern Sichuan Basin. Org. Geochem. 2014, 74, 3-12. [CrossRef]

66. Fishman, N.S.; Hackley, P.C.; Lowers, H.A.; Hill, R.J.; Egenhoff, S.O.; Eberl, D.D.; Blum, A.E. The nature of porosity in organic-rich mudstones of the upper Jurassic Kimmeridge clay formation, North Sea, offshore United Kingdom. Int. J. Coal Geol. 2012, 103, 32-50. [CrossRef]

67. Raiswell, R.; Berner, R.A. Pyrite formation in euxinic and semi-euxinic sediments. Am. J. Sci. 1985, 285, 710-724. [CrossRef]

68. Liao, W.; Wang, Y.B.; Kershaw, S.; Weng, Z.T.; Yang, H. Shallow-marine dysoxia across the Permian-Triassic boundary: Evidence from pyrite framboids in the microbialite in South China. Sediment. Geol. 2010, 232, 77-83. [CrossRef]

69. Guan, C.; Zhou, C.; Wang, W.; Wan, B.; Yuan, X.; Chen, Z. Fluctuation of shelf basin redox conditions in the early Ediacaran: Evidence from Lantian Formation black shales in South China. Precambrian Res. 2014, 245, 1-12. [CrossRef]

70. Tian, L.; Tong, J.; Algeo, T.J.; Song, H.; Chu, D.; Shi, L.; Bottjer, D.J. Reconstruction of Early Triassic ocean redox conditions based on framboidal pyrite from the Nanpanjiang Basin, South China. Palaeogeogr. Palaeoclim. Palaeoecol. 2014, 412, 68-79. [CrossRef]

71. Takahashi, S.; Yamasaki, S.; Ogawa, K.; Kaiho, K.; Tsuchiya, N. Redox conditions in the end-Early Triassic Panthalassa. Palaeogeogr. Palaeoclim. Palaeoecol. 2015, 432, 15-28. [CrossRef]

72. Wei, H.; Algeo, T.J.; Yu, H.; Wang, J.; Guo, C.; Shi, G. Episodic euxinia in the Changhsingian (late Permian) of South China: Evidence from framboidal pyrite and geochemical data. Sediment. Geol. 2015, 319, 78-97. [CrossRef]

73. Orr, W.L. Geologic and geochemical controls on the distribution of hydrogen sulfide in natural gas. In Advances in Organic Geochemistry; Enadisma: Madrid, Spain, 1977; pp. 571-597.

74. Cross, M.M.; Manning, D.A.; Bottrell, S.H.; Worden, R.H. Thermochemical sulphate reduction (TSR): Experimental determination of reaction kinetics and implications of the observed reaction rates for petroleum reservoirs. Org. Geochem. 2004, 35, 393-404. [CrossRef]

75. Dixon, S.A.; Summers, D.M.; Surdam, R.C. Diagenesis and preservation of porosity in Norphlet Formation (Upper Jurassic), southern Alabama. Am. Assoc. Pet. Geol. Bull. 1989, 73, 707-728.

76. Chen, J.; Xiao, X.M. Evolution of nanoporosity in organic-rich shales during thermal maturation. Fuel 2014, 129, 173-181. [CrossRef]

(C) 2019 by the authors. Licensee MDPI, Basel, Switzerland. This article is an open access article distributed under the terms and conditions of the Creative Commons Attribution (CC BY) license (http://creativecommons.org/licenses/by/4.0/). 